\title{
Genetics and molecular mechanisms of resistance to powdery mildews in tomato (Solanum lycopersicum) and its wild relatives
}

\author{
Alireza Seifi • Dongli Gao • Zheng Zheng • \\ Stefano Pavan • Luigi Faino • Richard G. F. Visser • \\ Anne-Marie A. Wolters • Yuling Bai \\ Accepted: 16 October 2013 / Published online: 5 December 2013 \\ (C) The Author(s) 2013. This article is published with open access at Springerlink.com
}

\begin{abstract}
Powdery mildews (PMs) cause disease in a wide range of plant species including important crops. Taking tomato as an example, here we review findings on the genetic basis and mechanisms of plant resistance to PMs. First, we present a summary of our research on tomato resistance to two PM species, with the focus on Oidium neolycopersici. We discuss the genetics of resistance to this pathogen in tomato. Then, we compare different forms of resistance mediated by different resistance genes based on molecular and cytological data. Also, we provide a comparison between these resistance genes in tomato with those in barley, Arabidopsis and wheat, in order to present a model for the genetic basis of resistance to PMs in plants. We try to accommodate these resistance mechanisms in the current model of plant innate
\end{abstract}

Alireza Seifi and Dongli Gao contributed equally.

A. Seifi $\cdot$ D. Gao $\cdot$ Z. Zheng $\cdot$ S. Pavan $\cdot$ L. Faino $\cdot$

R. G. F. Visser • A.-M. A. Wolters $•$ Y. Bai $(\bowtie)$

Wageningen UR Plant Breeding, Wageningen University and Research Centre,

Droevendaalsesteeg 1, 6708 PB Wageningen, Netherlands

e-mail: Bai.Yuling@wur.nl

Z. Zheng

Institute of Vegetables and Flowers, Chinese Academy of Agricultural Sciences,

Zhongguancunnandajie 12, 100081 Beijing, People's

Republic of China

S. Pavan

Department of Plant, Soil and Food Science, Section of Genetics and Plant Breeding, University of Bari,

Via Amendola 165/A, 70126 Bari, Italy immunity. At the end we discuss possibilities to translate these findings to practical approaches in breeding for resistance to PMs in crops.

Keywords Tomato $\cdot$ Powdery mildew $\cdot$ Resistance genes $\cdot$ Susceptibility genes $\cdot$ Resistance breeding

\section{Introduction}

Powdery mildews (PMs) are obligate biotrophic fungal pathogens that establish long-lasting interactions with their living host tissues by forming haustoria in plant cells. There are approximately 700 PM species capable of colonizing about 10,000 plant species (Braun and Cook 2012). These fungal pathogens produce discernible symptoms consisting of white colonies of mycelia on the surface of aerial green organs and sometimes on fruits upon heavy infection (Jones et al. 2001). The interaction of PMs with tomato, barley and Arabidopsis are well studied and, therefore, these pathosystems provide experimental models for understanding host and nonhost resistance to PMs (Bai et al. 2005; Hückelhoven 2005; Li et al. 2007; Schulze-Lefert and Vogel 2000).

Three PM species can infect tomato (Solanum lycopersicum), namely Oidium neolycopersici, $O$. lycopersici and Leveillula taurica. Upon the outbreak of O. neolycopersici in Europe in the late 1980s, all tomato cultivars turned out to be susceptible to this pathogen and this disease had to be controlled by using fungicides in greenhouse tomato production in 
Northwest Europe (Huang et al. 2000a). Requested and also supported by Dutch vegetable seed companies, we started our research on searching for resistance genes against this pathogen in 1996.

We have identified five dominant resistance genes (Ol-genes) from wild tomato species and introgressed them into cultivated tomatoes, and cloned one recessive gene (ol-2) that confers mlo-based broadspectrum resistance (Bai et al. 2005, 2008). In addition, we have mapped and introgressed three quantitative trait loci (QTLs) conferring different levels of resistance to $O$. neolycopersici. After many years, we have been able to set up tomato as the third wellcharacterized plant system, after barley and Arabidopsis, to study the interaction between plants and obligate PMs.

Plant innate immunity relies on a set of specialized receptors, so called pattern-recognition receptors (PRRs), which recognize microbe-associated molecules (Ausubel 2005). There are two groups of PRRs in plant cells: PAMP-receptors and resistance (R) proteins (in the literature PRR is sometimes used only to describe PAMP-receptors). PAMP-receptors are plant molecules that can perceive pathogenassociated molecular patterns (PAMPs), which are evolutionary conserved pathogen-derived molecules (i.e., chitin in fungi and flagellins in bacteria). $\mathrm{R}$ proteins are localized in the plasma membrane (like CF-2 and XA21 proteins) or, more frequent, in the intracellular area. The most common $\mathrm{R}$ proteins are the NBS-LRR proteins. Based on these two types of receptors, plant innate immune system has been divided into two distinct processes in a model known as Zig-Zag model (Jones and Dangl 2006). According to this model, perception of PAMPs by PAMPreceptors results in PAMP-triggered immunity (PTI), while $\mathrm{R}$ proteins perceive pathogen effectors (directly or indirectly) (Dangl and Jones 2001) and thereby, activate effector-triggered immunity (ETI) (Jones and Dangl 2006).

The study of plant-pathogen interactions involves communication between two living organisms, and thus, requires knowledge from both sides. Although we have characterized the mechanisms by which tomato respond to PM infection, the mechanism of $O$. neolycopersici pathogenicity is still largely unknown. One reason for this knowledge gap is that this obligate fungus needs to be maintained and propagated on tomato plants and, like other obligate PMs, is not easily amenable to molecular analysis (Bardin et al. 2007). Moreover, its sexual stage has not been reported so far, and this hampers genetic studies on this fungus (Lebeda et al. 2013). One way to compensate this shortage of knowledge is to explore the discovered mechanisms of pathogenicity in other PM species. Till now, a few fungal effectors have been cloned including two effectors from Blumeria graminis f. sp. hordei $(B g h)$, the causal agent of barley PM disease (Kamoun 2007). Thanks to recent advances in next generation sequencing technologies, the genomes of three PM species (Bgh infecting barley, Erysiphe pisi infecting pea and Golovinomyces orontii infecting Arabidopsis) have been sequenced and a pile of information of putative effectors in these PMs is now available (Spanu et al. 2010).

In this review, we first summarize the genetics, specificity and (molecular) mechanisms of tomato resistance to powdery mildews, with the focus on the $O l$-genes and QTLs identified for resistance to $O$. neolycopersici. We then compare the genetics and mechanisms of tomato defense against $O$. neolycopersici with that in barley and Arabidopsis in response to their adapted PM species, in order to understand common mechanisms, if any, by which plants defend themselves against PMs. Further, we discuss the resistance to different PMs in the context of PTI and ETI. Finally, we present our thoughts on potential approaches for achieving durable resistance to PMs in crops.

\section{Powdery mildews infecting tomato}

\section{Oidium lycopersici and O. neolycopersici}

The first report on tomato PM dates back to the late $19^{\text {th }}$ century when $O$. lycopersici was found in Australia (Cooke and Massee 1888). After almost a century an epidemic of tomato PM occurred in the Netherlands and spread within the next 10 years to all European countries. O. lycopersici was initially assumed to be the cause for this epidemic, however, later studies discovered that the causal agent is $O$. neolycopersici (Jones et al. 2000, 2001; Kiss et al. 2001). Now it is believed that $O$. neolycopersici is present worldwide, except in Australia where $O$. lycopersici is the causal agent for PM disease in tomato (Kiss et al. 2001, 2005). Although there is not a 
consensus on the host range of $O$. neolycopersici (Jones et al. 2001; Lebeda et al. 2013), there is some evidence suggesting that this pathogen is adapted to plant species from 13 plant families (Whipps et al. 1998; Jankovics et al. 2008). For further information of $O$. lycopersici and $O$. neolycopersici, please see the comprehensive review by Lebeda et al. (2013).

\section{Leveillula taurica}

Another PM fungus that can infect tomato is Leveillula taurica (Lév.) Arnaud (asexual state Oidiopsis taurica (Lév.) Salmon). Morphologically, L. taurica can be easily distinguished from $O$. neolycopersici. The mycelia of L. taurica grow through the mesophyll and are visible on the abaxial side of the leaf, while $O$. neolycopersici grows mainly on the adaxial side and does not penetrate into the mesophyll (Lindhout et al. 1994).

L. taurica is an important pathogen of tomato in hot and dry tropical to sub-tropical zones, and in glasshouses (Blancard 2012). It can also infect pepper, eggplant, cucumber, onion, cotton and other crops, as well as many wild plant species (Braun and Cook 2012). In total, more than 1,000 species belonging to 74 botanical families are hosts for L. taurica (Palti 1988). Molecular analyses revealed that $L$. taurica is actually an aggregate species consisting of several biological lineages, for which the exact host range is not known (Khodaparast et al. 2001, 2007, 2012).

While $O$. neolycopersici is epiparasitic, as most other powdery mildew species are, L. taurica grows endophytically. In tomato, after germination of conidia on the leaf surface the hyphae enter the leaf directly by perforating the cuticle, and subsequently develop an intercellular mycelium in the mesophyll tissue. Infection hyphae grow into the spongy and sometimes the palisade parenchyma tissues. Penetration pegs penetrate the host's cell wall followed by the development of haustoria (Palti 1988). After a latency period of approximately 20 days conidiophores emerge from stomata, mainly on the abaxial leaf surface, and produce spearheaded terminal conidia (Blancard 2012). Usually, at this stage bright yellow spots are visible on the adaxial leaf surface and become necrotic later. Eventually, the complete leaf may turn yellow, shrivel and dry up, but it remains attached to the plant. At this stage fruits are exposed to destructive sun scorch, resulting in economic losses (Palti 1988). It is worthwhile to note that the infection process of $L$. taurica in tomato is different from that in pepper (Zheng et al. 2013a).

\section{The genetics and mechanisms of resistance to powdery mildews in tomato (Solanum lycoperisum) and its wild relatives}

Cultivated tomato has limited variability, largely because of artificial selection during domestication and development of modern cultivars. To improve disease resistance and agronomic traits, tomato wild germplasm is a useful resource (Bai and Lindhout 2007).

\section{Resistance to L. taurica}

Tomato cultivars differ greatly in their susceptibility to L. taurica (Palti 1988). Resistant accessions of $S$. lycopersicum var. cerasiforme and wild tomato species S. chilense, S. habrochaites and S. peruvianum have been reported (Palti 1988; Hernandes and Stamova 1990). The dominant resistance gene $L v$ from $S$. chilense accession LA1969 (Yordanov et al. 1975; Stamova and Yordanov 1987, 1990) is effective against $L$. taurica, but not against $O$. neolycopersici (unpublished data). This gene, which is mapped on chromosome 12, confers resistance via inducing hypersensitive response (HR) (Chungwongse et al. 1994, 1997). The $L v$ gene has been the only gene in tomato germplasm for resistance to $L$. taurica. The recessive ol-2 gene (Ciccarese et al. 1998; Bai et al. 2008) identified in S. lycopersicum var. cerasiforme confers incomplete resistance to L. taurica (Zheng et al. 2013b).

\section{Resistance to $O$. neolycopersici}

$O$. neolycopersici was only distinguished from $O$. lycopersici in 2001 by Kiss et al. (2001). As far as we know no specific resistance genes for $O$. lycopersici have been reported. Although resistance sources against $O$. lycopersici were published, they proved to be resistances against $O$. neolycopersici. Thus, there is no report on resistance to O. lycopersici and it is unknown whether the identified resistance sources to $O$. neolycopersici are also effective to $O$. lycopersici. 
Mapped loci for resistance to O. neolycopersici in tomato

Whereas no effective sources of resistance to $O$. neolycopersici have been found in tomato cultivars released by the end of $20^{\text {th }}$ century, several resistant accessions have been discovered in wild tomato species (Lebeda et al. 2013). Till now, nine loci have been mapped which confer resistance to $O$. neolycopersici (Fig. 1). Ol-1, identified from S. habrochaites G1.1560 (Van der Beek et al. 1994), has been mapped on the long arm of tomato chromosome 6 (Bai et al. 2005). ol-2 is a recessive resistance gene found in S. lycopersicum var. cerasiforme LA1230 and is located on chromosome 4 (Ciccarese et al. 1998). Cloning of this gene revealed that $o l-2$ is a homologue of the barley Mlo gene (Bai et al. 2008). Ol-3, introgressed from $S$. habrochaites G1.1290, is located in the same chromosomal region as $\mathrm{Ol}-1$. There is some evidence suggesting that $\mathrm{Ol}-1$ and $\mathrm{Ol}-3$ are allelic variants (Huang et al. 2000b; Bai et al. 2005). Ol-4, originating from S. peruvianum LA2172, is located on the short arm of chromosome 6 (Bai et al. 2004). Ol-5, introgressed from $S$. habrochaites PI247087, is closely linked to $O l-1$ and Ol-3 on the long arm of chromosome 6 (Bai et al. 2005). $\mathrm{Ol}-6$, which was found in an advanced breeding line with unknown origin, is mapped in the same position as $\mathrm{Ol}-4$ (Bai et al. 2005). Very likely, Ol-4 and Ol-6 are allelic variants. On the short arm of tomato chromosome 6 , a cluster of disease resistance $(R)$ genes has evolved from the $M i-1$ gene that confers resistance to root-knot nematodes (Meloidogyne spp.), potato aphids (Macrosiphum eluphorbiae), and whiteflies (Bemisia tabaci and B. tabaci biotype B) (Milligan et al. 1998; Rossi et al. 1998; Nombela et al. 2003). Silencing Mi-1 homologues in tomato lines carrying $\mathrm{Ol}-4$ and $\mathrm{Ol}-6$ compromised the resistance to $O$. neolycopersici in those lines, demonstrating that $\mathrm{Ol}-4$ and $\mathrm{Ol}-6$ are $\mathrm{Mi}-\mathrm{I}$ homologues (Seifi et al. 2011). In addition to these monogenic resistance genes, three quantitative trait loci (Ol-qtls) were identified in S. neorickii G1.1601 (Bai et al. 2003). Ol-qtll was mapped on chromosome 6 in a chromosomal region where $\mathrm{Ol}-1, \mathrm{Ol}-3$ and $\mathrm{Ol}-5$ are located. Ol-qtl2 and Ol-qtl3 were mapped on chromosome 12 in the vicinity of the $L v$ gene (Bai et al. 2003). Ol-qtl1 and Ol-qtl2 were further finemapped using advanced populations, while the presence of Ol-qtl3 needs to be further confirmed (Fig. 1) (Faino et al. 2012).
Mechanisms associated with resistance conferred by the $\mathrm{Ol}$-genes and $\mathrm{Ol}$-qtls

The resistance mechanisms associated with $\mathrm{Ol}$-genes and Ol-qtls have been studied by using a unique set of nearly isogenic lines (NILs), which harbour an introgression carrying the particular $\mathrm{Ol}$-gene/QTL in the genetic background of S. lycopersicum cv. Moneymaker (MM) (Bai et al. 2005; Li et al. 2012). These NILs have been compared for their response to $O$. neolycopersici based on histological and biochemical events, changes in gene expression pattern, and fluctuation in phytohormone pathways during infection with $O$. neolycopersici (Bai et al. 2005; Li et al. 2007, 2012; Seifi 2011).

Histological characteristics of resistance conferred by different $\mathrm{Ol}$ genes

Plant cell death is one of the resistance mechanisms against biotrophic pathogens by delimiting pathogen progress on plant tissue. HR is a form of cell death triggered typically upon recognition of pathogen avirulence (Avr) proteins by plant $\mathrm{R}$ proteins (Nimchuk et al. 2003). HR has been reported to be associated with resistance conferred by the dominant $\mathrm{Ol}$-genes (Huang et al. 1998; Bai et al. 2005). Particularly, two different forms of HR have been observed in the tomato response to O. neolycopersici. Single-cell HR (Huang et al. 1998; Bai et al. 2005), also defined as fast HR (Li et al. 2007) happens in the presence of $\mathrm{Ol}-4$ and $\mathrm{Ol}-6$. These two $\mathrm{Ol}$ genes are homologous to the $M i-1$ gene encoding an NBS-LRR protein (Seifi et al. 2011). This type of HR occurs in all intruded epidermal cells in which primary haustoria are formed, resulting in a complete stop of fungal growth (Bai et al. 2005). On the other hand, multiple-cell HR (Huang et al. 1998; Bai et al. 2005), also described as slow HR (Li et al. 2007) occurs in tomato plants carrying $\mathrm{Ol}-1, \mathrm{Ol}-3$ and $\mathrm{Ol}-5$. Interestingly, these three $\mathrm{Ol}$-genes originate from different accessions of $S$. habrochaites and cluster together on the long arm of tomato chromosome 6 (Fig. 1) (Bai et al. 2003). Since such type of HR occurs only in about $30 \%$ of infected cells, fungal colonization is not prevented completely and thus leads to an incomplete resistance.

The recessive gene, ol-2, which is a homologue of the barley $M L O$ gene, mediates resistance by formation of papillae, i.e., cell wall appositions of callose and other constituents at plant-PM interaction sites (Bai et al. 2003, 2008). Papillae are formed before and/or 
Fig. 1 Physical map of tomato chromosomes 4, 6 and 12 showing the positions of markers on the left (blue lines) and powdery mildew resistance genes and QTL regions on the right (red lines and boxes). Positions are indicated in Mega basepairs (Mbp), based on the Heinz SL2.40 tomato genome sequence (http:// solgenomics.net)

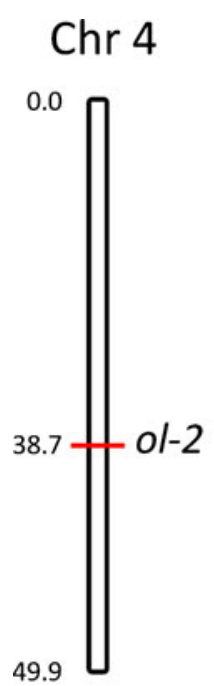

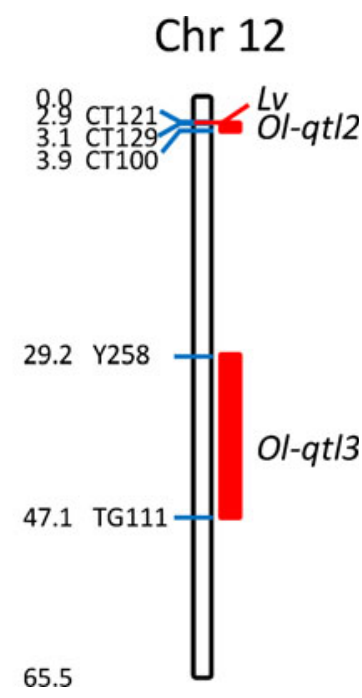

immediately after the formation of primary haustoria, resulting in early stop of fungal growth and leading to a complete resistance.

Interestingly, the resistance in NILs carrying Ol-qtls is associated with HR and papilla formation, though cell death is predominant ( $\mathrm{Li}$ et al. 2012). Three types of HR have been described, micro-HR (similar to fast HR), particle-HR (similar to slow HR) and micro/particle HR. The last one has not been observed in NILs carrying dominant $\mathrm{Ol}$-genes. The three QTLs jointly confer a very high level of resistance.

Biochemical characteristics of resistance conferred by different $O l$ genes

Accumulation of reactive oxygen species (ROS, e.g., $\mathrm{H}_{2} \mathrm{O}_{2}$ ) upon pathogen attack is one of the earliest events that occur in host cells, a phenomenon known as oxidative burst (OB) (Lamb and Dixon 1997). The apoplastic OB occurs rapidly due to the function of membrane enzymes, NADPH oxidases, peroxidases, amine oxidases, and oxalate oxidases (Hückelhoven 2007). In compatible interactions there is a weak induction of $\mathrm{OB}$, however, in incompatible interactions a second OB with higher magnitude occurs (Lamb and Dixon 1997). The ROS produced in OB are antimicrobial agents. In addition, $\mathrm{H}_{2} \mathrm{O}_{2}$ contributes to cell wall fortification, induces cell death, and acts as a diffusible signal for induction of systemic defence response (Lamb and Dixon 1997; Torres et al. 2006). The role of $\mathrm{H}_{2} \mathrm{O}_{2}$ in the cell wall fortification is both in cross-linking of the cell wall proteins and also in

serving as a substrate in cell wall apposition (papilla formation) (Hückelhoven 2007).

Accumulation of $\mathrm{H}_{2} \mathrm{O}_{2}$, occurrence of cell death, and deposition of callose in tomato in response to $O$. neolycopersici has been monitored (Mlíčková et al. 2004; Tománková et al. 2006). In comparison with susceptible tomatoes ( $S$. lycopersicum), the level of $\mathrm{H}_{2} \mathrm{O}_{2}$ increased significantly in resistant wild species, $S$. habrochaites and $S$. chmielewskii in which HR occurred (Mlíčková et al. 2004; Tománková et al. 2006). We have also studied $\mathrm{H}_{2} \mathrm{O}_{2}$ accumulation and callose deposition in different NILs at different timepoints after infection with $O$. neolycopersici ( $\mathrm{Li}$ et al. 2007, 2012). Our results showed that both HR and papilla formation in tomato attacked by $O$. neolycopersici are associated with $\mathrm{H}_{2} \mathrm{O}_{2}$ and callose accumulation ( $\mathrm{Li}$ et al. 2007, 2012). In the susceptible $\mathrm{MM}$ and a NIL carrying the ol-2 gene (NIL-ol-2), $\mathrm{H}_{2} \mathrm{O}_{2}$ accumulation in epidermal cells is almost absent. In contrast, in NILs carrying Ol-1 (NIL-Ol-1), Ol-4 (NIL-Ol-4) and Ol-qtls (NIL-Ol-qtls), $\mathrm{H}_{2} \mathrm{O}_{2}$ accumulates in every cell that underwent cell death, consistent with the results of previous works (Mlíčková et al. 2004; Tománková et al. 2006). In cells undergoing HR, callose deposition was also observed. At the first interaction sites (where primary appressoria are formed), both $\mathrm{H}_{2} \mathrm{O}_{2}$ accumulation and callose deposition was more abundant in NIL-ol-2 and NILOl-1 compared with other lines, however, only in NILol-2 the deposited callose formed papillae. In the latest stage of infection (41 h post inoculation) in MM and NIL-Ol-1 callose deposition was observed at about 
$60 \%$ of the first interaction sites, where the fungus penetrates the epidermal cells, indicating that the timing of callose deposition is relevant for the outcome of resistance/susceptibility in the interaction of tomato and O. neolycopersici (Li et al. 2007, 2012).

Reprogramming of gene expression associated with different $O l$ genes

In order to compare the resistance mechanism mediated by monogenic $\mathrm{Ol}$ genes and $\mathrm{Ol}-q \mathrm{tl}$, we studied the transcript profiles by cDNA-AFLP (Li et al. 2006, 2007) and microarray analysis (unpublished data).

cDNA-AFLP profiling clarified that the majority of the up-regulated differentially expressed-transcript derived fragments (DE-TDFs) are common in MM, NIL-Ol-1 and NIL-Ol-qtls, with differences in timing of expression for certain DE-TDFs (Li et al. 2006, 2007, 2012). This similarity is likely due to the fact that slow $\mathrm{HR}$ is involved in the resistance mediated by $\mathrm{Ol}-1$ and $\mathrm{Ol}$-qtls, resulting in a similar pattern of fungal growth in MM and NILs carrying Ol-1 and Ol-qtls (Li et al. 2007, 2012). Most of these sequenced inducible transcripts showed homology to genes with functions in defence responses, implying that $\mathrm{Ol}-1$ - and $O \mathrm{O}$-qtls-mediated responses likely employ overlapping components of defence pathways occurring in basal immunity, however the timing and magnitude of responses may determine the interaction outcome ( $\mathrm{Li}$ et al. 2006, 2012). Though the resistance mediated by $\mathrm{ol}-2$ is associated with papilla formation, distinct from HR, more than $50 \%$ of the DETDFs that were induced in NIL-Ol-1 also showed upregulation in NIL-ol-2 (Li et al. 2007). This unexpected result may be explained by the fact that papilla formation occurred only in about $40 \%$ of the ol-2 epidermal cells attacked by primary appressoria (Bai et al. 2005). In contrast, NIL-Ol-4 showed a highly divergent set of DE-TDFs compared with the ones from NIL-Ol-1. For example, more than $70 \%$ of the DETDFs that were up-regulated in NIL-Ol-1 were not detected in NIL-Ol-4 (Li et al. 2007).

Microarray analysis was performed using RNA extracted from PM-inoculated and mock-inoculated leaf samples at 1, 5 and 7 days post inoculation (dpi) on the tomato Syngenta Affymetrix array (unpublished data). Of the 22,000 genes on the array, the expression of about 250 genes was different at least between two of the samples. Interestingly, these genes are mainly differentially expressed between NILs and MM, regardless of the pathogen infection. In NIL-ol-2 and NIL-Ol-4 the number of genes showing significant differential expression compared to MM (fold change above 2, $p<$ 0.01 ) is higher than that in NIL-Ol-1 (Fig. 2). The narrower range of differentially expressed genes in NILOl-1 suggested that compared to NIL-ol-2 and NIL-Ol-4 the response of NIL-Ol-1 upon PM attack is more similar to $\mathrm{MM}$, which is in agreement with the results obtained from cDNA-AFLP analysis (Li et al. 2006, 2007).

The fact that our microarray study revealed only differences in constitutive gene expression in different genotypes, but not upon fungal inoculation within the genotype, may be due to the sampling method. We collected entire infected leaves and isolated RNA for microarray analysis. It is worth mentioning that PM only infects the epidermal cell layer and, therefore, it is expected that molecular events associated with the infection occur in this cell layer. Micro-dissection of the epidermal cell has been shown to be an effective approach to get a better understanding of gene expression reprogramming upon PM infection. In the Arabidopsis - G. orontii pathosystem, the epidermal cell layer was first microdissected by using laser and then the gene expression pattern was studied in the collected cells (Chandran et al. 2010). This elegant experiment revealed involvement of new genes, including 67 transcription factors, in response to PMs that have not been discovered before by whole tissue analysis. Interestingly, one of these transcription factors, known as MYB3R4, induces endoreduplication in the infected cells, probably to increase the metabolism of the plant cell in the favour of the pathogen (Chandran et al. 2010).

In barley, genes have been identified that are required for the resistance mediated by certain Mla genes (e.g. Rar1, Rar2), as well as for mlo (Ror1 and Ror2) (Freialdenhoven et al. 1994, 1996; Hückelhoven et al. 2001). In tomato, silencing a putative glutathione $S$ transferase (GST) compromised the resistance conferred by the $\mathrm{Ol}-1$ gene (Pei et al. 2011). We are performing functional analysis of genes showing differential expression between MM and the NILs and expect to find different genes essential for specific $\mathrm{Ol}$ genes.

RNA silencing in PM resistance

There is overwhelming evidence implicating plant RNA silencing pathways in plant defence responses to viruses, bacteria, oomycetes, and fungi (reviewed by Katiyar-Agarwal and Jin 2010; Ruiz-Ferrer and 

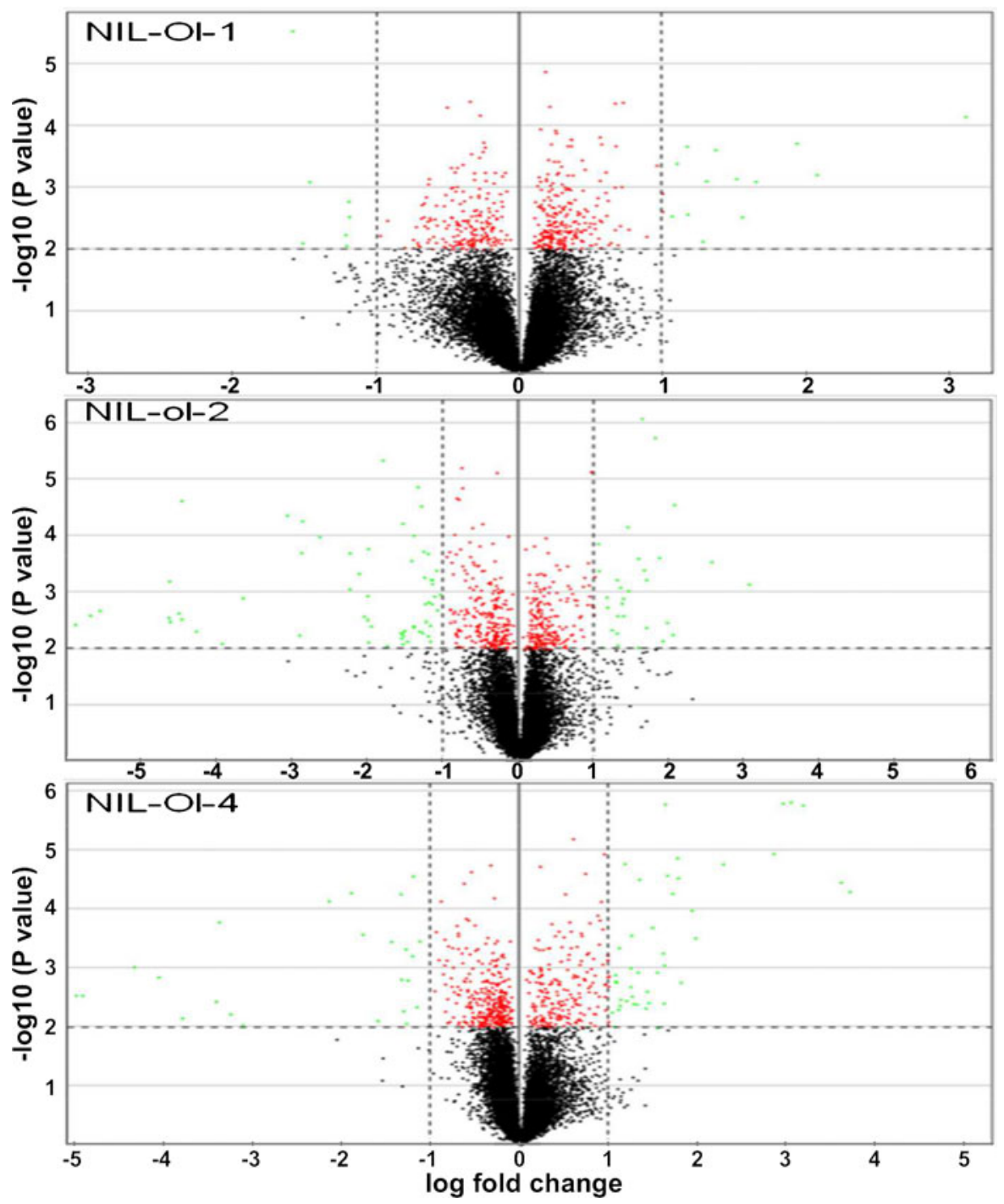

Fig. 2 Volcano plot representing the differences in fold change in gene expression in different NILs compare to MM, challenged with $O$. neolycopersici. Total RNA from MM, NIL-Ol-1, NIL-ol2, and NIL-Ol-4 leaf tissue collected at 1, 5, or 7 days after inoculation with Oidium neolycopersici or spraying with water was isolated. This RNA was hybridized to the tomato Syngenta Affymetrix array (van Esse et al. 2009) and the data were normalized by RMA (robust multi-array) method. The MeV free software (www.tm4.org/mev) was used to analyse the data. In each plot, the $\mathrm{X}$ axis shows differences in fold change in the gene

Voinnet 2009; Seo et al. 2013). To be cost effective, defence responses need to be suppressed during normal conditions and to be rapidly activated upon pathogen attack. Endogenous gene silencing is suggested to be one of the mechanisms for this rapid expression between each NIL and MM, and the Y axis shows the probability ( $\log p$ value) of the differences. Horizontal dashed line determines the threshold 2 for probability $(p=0.01)$ of significance and the vertical dashed lines set the threshold 1 for difference in fold change of gene expression. The green dots show genes which expression level is at least 1 fold different in a NIL compare to MM, with $p<0.01$. The positive values on the $\mathrm{X}$ axis indicate higher expression in NILs compare to MM, and negative values indicate lower expression in NILs compare to MM

“off” and “on" regulation (Jin 2008). In agreement with this idea, recently a miR482/2118 superfamily was discovered in tomato that silences numerous NBS-LRR genes, and upon pathogen infection this silencing mechanism is suppressed (Shivaprasad et al. 2012). 
RNA silencing (also called RNA interference, RNAi) is the most common antiviral mechanism in plants, and thus, viruses interfere with their host's RNA silencing pathways (reviewed by Voinnet 2005). Such an ability had not been reported for other pathogens, until recently that Qiao and co-workers demonstrated that several effectors of Phytophtora sojae supress the RNA silencing in plants by inhibiting the biogenesis of small RNAs (Qiao et al. 2013).

It has been shown that expression of RNAi constructs for Blumeria effectors (Avra10 and AvraKl) and Glucanosyltransferase genes in barley results in a reduction in fungal development (Nowara et al. 2010). Whether this host-induced gene silencing (HIGS) degrades fungal transcripts inside the pathogen or inside the plant cells is not certain yet, but the fact that some of the silenced genes function inside the pathogen and also there is no evidence for secretion of Avra 10 and AvraK1 transcripts inside epidermal cells, favours the scenario that silencing occurs inside the pathogen (Nowara et al. 2010). This phenomenon may suggest the involvement of RNA silencing in plant response to PMs.

Interestingly, we also have data suggesting that $O$. neolycopersici suppresses tomato RNA silencing pathways in order to establish pathogenicity. We discovered that the expression of a regulator of gene silencing is strongly induced in tomato plants infected with O. neolycopersici (Seifi 2011). From the microarray dataset mentioned before we found a subset of genes that were highly up-regulated in the early stages of infection in the compatible interaction compared to the incompatible interactions (unpublished data). One of these genes is a calmodulin-like regulator of gene silencing (known as rgs-CaM; GeneBank accession: AY642285). An ortholog of this gene in tobacco is induced in response to tobacco mosaic virus (Anandalakshmi et al. 2000; Nakahara et al. 2012). We verified the expression of this gene in our NILs as well as in MM, and results clearly showed that this gene is indeed induced drastically in MM (compatible interaction) in the early time-points (Fig. 3). This suggests that probably $O$. neolycopersici manipulates the tomato RNA silencing machinery in $\mathrm{MM}$ in order to establish a compatible interaction. However, in incompatible interactions, when resistance genes are present, this interference is significantly decreased, proportional to the strength of the corresponding resistance genes. We are currently investigating this interesting gene in more details.
Phytohormone pathways involved in resistance conferred by $\mathrm{Ol}$-gene/Ol-qtls

Plant hormone signalling pathways are an important part of downstream pathways in immunity responses. Ample evidence has shown that salicylic acid (SA), jasmonic acid (JA), ethylene (ET), auxin, abscisic acid (ABA), and gibberellic acid (GA), cytokinin and brassinosteroid signalling pathways play a role in defence (Grant and Jones 2009; Bari and Jones 2009). In general, SA and JA are believed to be signalling molecules in defence against biotrophic and necrotrophic pathogens, respectively (Glazebrook 2005). The SA pathway is well-documented as an essential component in ETI, PTI and systemic acquired resistance (Vlot et al. 2009). JA in the presence of low levels of ET is only able to trigger a response to herbivores and wounding, while in combination with high ET levels, it triggers responses to necrotrophs as well (Grant and Jones 2009). ABA is mainly considered as a negative regulator of plant immunity (Mauch-Mani and Mauch 2005), probably because of its antagonistic interaction with the ET-JA signalling pathways (Anderson et al. 2004). SA, JA and ET pathways are considered as the backbone of phytohormone networks in the plant immune system, with which auxin, ABA, and GA pathways interact (Pieterse et al. 2009).

In tomato responses to $O$. neolycopersici, only the involvement of phytohormones in basal defence has been studied to some extent. Results suggested that the SA pathway has no role in basal defence (Achuo et al. 2004; Lebeda et al. 2013), but ABA-deficiency or ETinsensitivity enhances basal resistance in tomato against biotrophs including $O$. neolycopersici (Achuo et al. 2006; Lund et al. 1998).

We did a different study and compared the hormonal pathways in different tomato-PM interactions using the NILs carrying the $\mathrm{Ol}$-genes and Ol-qtls (Seifi 2011). An early significant induction in the SA pathway was observed in NIL-Ol-4 (Li et al. 2007; Seifi 2011). The $\mathrm{Ol}-4$ gene is a homologue of the $\mathrm{Mi}-1$ gene, and triggers accumulation of $\mathrm{H}_{2} \mathrm{O}_{2}$ and induction of $\mathrm{HR}$ at 1 dpi upon PM infection ( $\mathrm{Li}$ et al. 2007). Given the important role of SA in HR induction (Vlot et al. 2009; Love et al. 2008), the early induction in SA pathway in NIL-Ol-4 is expected. Interestingly, SA is required for the $M i$-1-mediated resistance to potato aphids, but not to nematodes ( $\mathrm{Li}$ et al. 2006; Mantelin et al. 2013). 
Fig. 3 The expression pattern of a regulator of RNA silencing in different tomato interactions with Oidium neolycopersici. MM is the susceptible line to $O$. neolycopersici, and is the background for near isogenic lines (NILs), harbouring different resistance genes to PM. NIL-Ol-4 and NIL-ol-2 show a high level of resistance to $O$. neolycopersici, while NIL-Ol-1 is partially resistant. Error bars show standard deviation (Adapted from Seifi 2011)

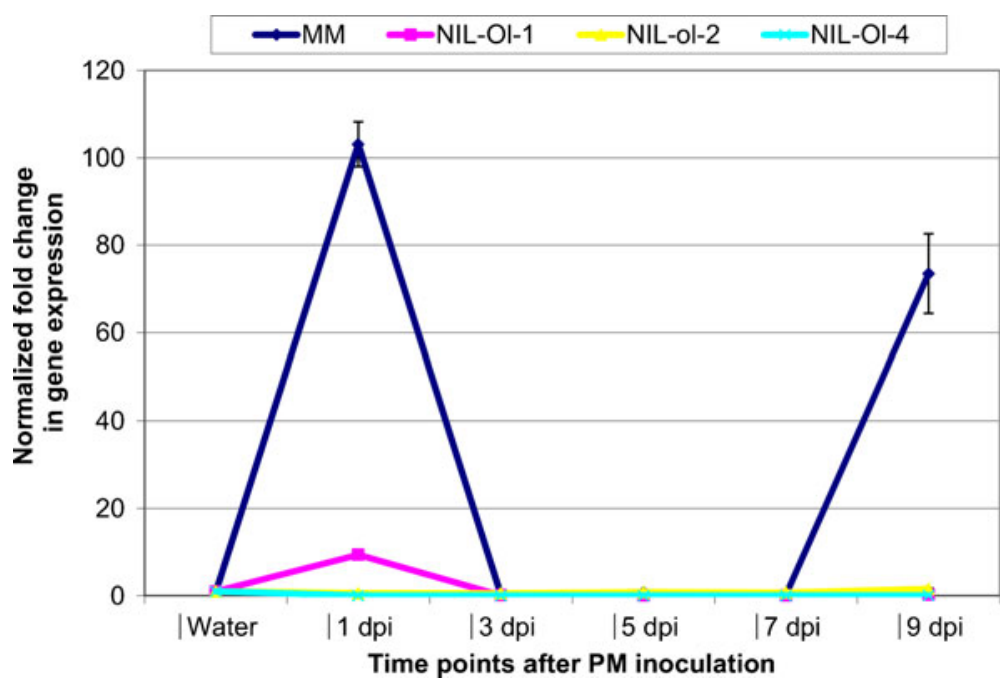

These results highlight the diverse modes of hormone signalling pathways in resistance conferred by $\mathrm{Mi}-1$ homologues. Although we provide evidence suggesting that the SA pathway plays a role in $\mathrm{Ol}-4$ mediated resistance to $O$. neolycopersici, further confirmations are required to reach a more definite conclusion, for instance by testing the $\mathrm{Ol}-4$ function in a mutant deficient in the SA pathway. In contrast to the SA pathway, JA, ABA and ET pathways in NILOl-4 showed the same trend as in the susceptible genotype MM. Accordingly, disruptions of the ET, $\mathrm{JA}$ and ABA pathways had no effect on $\mathrm{Ol}$-4-mediated resistance (Seifi 2011).

In NIL-Ol-1 and NIL-Ol-qtls, ET pathway induction started from $7 \mathrm{dpi}$ and reached a maximum level at 9 dpi in NIL-Ol-1 (Seifi 2011). In contrast, the other NILs showed the same pattern as that observed in MM. Further, ET-insensitivity compromises the PM resistance in these two NILs. Late induction of the SA pathway was also observed in NIL-Ol-1 and NILOl-qtls, which is distinguishable from the induction in other lines. The involvement of the SA pathway in resistance conferred by $\mathrm{Ol}-1$ and $\mathrm{Ol}$-qtls needs to be further studied

In MM and the NILs, marker genes for JA and ABA pathways showed a constant level of expression in the period of infection followed by an induction during late stages of infection with the highest rate in MM (Seifi 2011). Late accumulation of ABA and JA in compatible interactions of tomato with other pathogens has also been reported by others (O'Donnell et al. 2003; De Torres-Zabala et al. 2007; Fan et al. 2009), which suggests that this accumulation is the result of disease establishment and stress rather than a defence response. Surprisingly, ABA-deficiency compromised resistance mediated by both ol-2 and Ol-qtls. ABA induces callose deposition (Flors et al. 2005; Flors et al. 2008), which is the main mechanism of resistance mediated by ol-2 (Bai et al. 2008) and is also triggered by $\mathrm{Ol}$-qtls (Li et al. 2007). Thus, we assume that a basal level of induction of the ABA pathway is required for the process of callose deposition that contributes to the resistance mediated by $o l-2$ and $O l-q t l s$.

In addition to ABA, JA-deficiency also compromised ol-2-mediated resistance. The resistance conferred by the recessive ol-2 gene is due to the lossof-function of MLO (Bai et al. 2008), a transmembrane protein accumulating at attempted fungal penetration sites in plasma membrane microdomains (Bhat et al. 2005). In barley, Arabidopsis and tomato, loss-offunction mutation in Mlo homologues results in resistance to different PM species, demonstrating that MLO represents a conserved plant host cell protein required in PM pathogenesis (Consonni et al. 2006). In Arabidopsis, mlo-based resistance to Golovinomyces spp. is largely independent from SA, JA and ET pathways. However, our data showed that the SA pathway was induced at $1 \mathrm{dpi}$ in NIL-ol-2 and that impairment of $\mathrm{ABA}$ and JA pathways compromised ol-2-mediated resistance. Thus, molecular mechanisms underlying the mlo-mediated resistance in tomato and Arabidopsis are not completely the same. Considering that the JA pathway is involved in regulating programmed cell death $(\mathrm{PCD}$; Reinbothe et al. 2009), and that MLO protein is a negative regulator of PCD (Shirasu and Schulze- 
Lefert 2000), the involvement of the JA pathway in ol2-mediated resistance is conceivable. It is intriguing how SA, JA and ABA signalling pathways are coordinated in ol-2-mediated resistance that is associated with cell wall apposition but not with PCD.

Specificity of the resistance conferred by the $\mathrm{Ol}$-genes and Ol-qtls

O. neolycopersici is a highly polyphagous fungus (Jones et al. 2001) and the presence of different races has been reported in different parts of the world (Lebeda et al. 2013). Using our NILs, we have shown that resistance conferred by the $\mathrm{Ol}-4$ and $\mathrm{Ol}-6$ genes can be overcome by the isolate from Czech Republic and one of the two Japanese isolates (KTP-02) (Bai et al. 2005; Seifi et al. 2012). The resistance conferred by other $\mathrm{Ol}$-genes and $\mathrm{Ol}$-qtls remain effective to all the tested isolates (Bai et al. 2005; Li et al. 2012).

Resistance to PMs in different crops

\section{An overview of resistance to $O$. neolycopersici in tomato}

In summary, resistance to $O$. neolycopersici identified so far in tomato can be classified into four categories based on the genetics, mechanisms and specificities of the resistance conferred by the $\mathrm{Ol}$-genes and Ol-qtls (Table 1). The comparison of these different forms of resistance based on the histological characteristics, trend of phytohormone pathways, and level of resistance is illustrated in Fig. 4.

- The first category is the incomplete and broadspectrum resistance that is controlled by dominant genes (Ol-1, Ol-3 and Ol-5). All the three genes originated from $S$. habrochaites accessions cluster on the long arm of chromosome 6. Histologically, slow HR is associated with the resistance conferred by these genes (Bai et al. 2005; Li et al. 2007). The ET pathway plays a role in the $O l-1$-mediated resistance. Though in NIL-Ol-1 fungal growth pattern is similar to that in susceptible MM, slow $\mathrm{HR}$ in NIL-Ol-1 is effective enough to prevent further pathogen progress leading to incomplete and broad-spectrum resistance. Also, similar molecular events are observed in NIL-Ol-1 and MM (Li et al. 2006, 2007). Thus we suggest that
$O l-1$, and likely $O l-3$ and $O l-5$, encode enhancers of basal defence, which induce delayed cell death in the later stages of pathogen infection.

- The second category is the complete and racespecific resistance conferred by dominant $\mathrm{Ol}-4$ and Ol-6 genes, which are derived from $S$. peruvianum and an unknown genetic resource, respectively. These genes encode CC-NBS-LRR proteins (Seifi et al. 2011) and induce fast HR in the very early stages of pathogen attack (Bai et al. 2005; Li et al. 2007). This HR prevents further fungal development and the pathogen can hardly produce any secondary haustoria (Li et al. 2007), resulting in complete resistance. As expected for HR-mediated resistance, the SA pathway is induced in NIL-Ol-4 at early time-points after pathogen infection (Seifi 2011).

- The third category is the recessive and broadspectrum resistance controlled by the recessive ol2 gene and associated with papilla formation (Bai et al. 2008), with involvement of ABA and JA pathways (Seifi 2011).

- The fourth category is polygenic and broadspectrum resistance that is governed by three QTLs identified in S. neorickii G1.1601 (Bai et al. 2003; Faino et al. 2012) and associated with a combination of HR and papilla formation ( $\mathrm{Li}$ et al. 2012). ET and ABA pathways contribute to this type of resistance (Seifi 2011).

Comparison of PM resistance in tomato and barley

In the well-studied barley and barley powdery mildew $(B g h)$ pathosystem, many resistance genes have been characterized (Schulze-Lefert and Vogel 2000). Based on genetics and histological characteristics, these genes can be classified briefly into three groups. The first one is the recessive resistance conferred by lossof-function alleles of the Mlo gene (e.g., mlo-5), which arrests fungal development at the penetration stage while the attacked cells stay alive. The second one is represented by a subset of dominant Mla (e.g. Mla1, Mla6 and Mla13) and Mlg genes, conferring complete resistance at the penetration stage by inducing a singlecell HR reaction. The third one includes a subset of dominant Mla genes (e.g., Mla 7, Mla10 and Mla12), which confer incomplete resistance by inducing multi- 


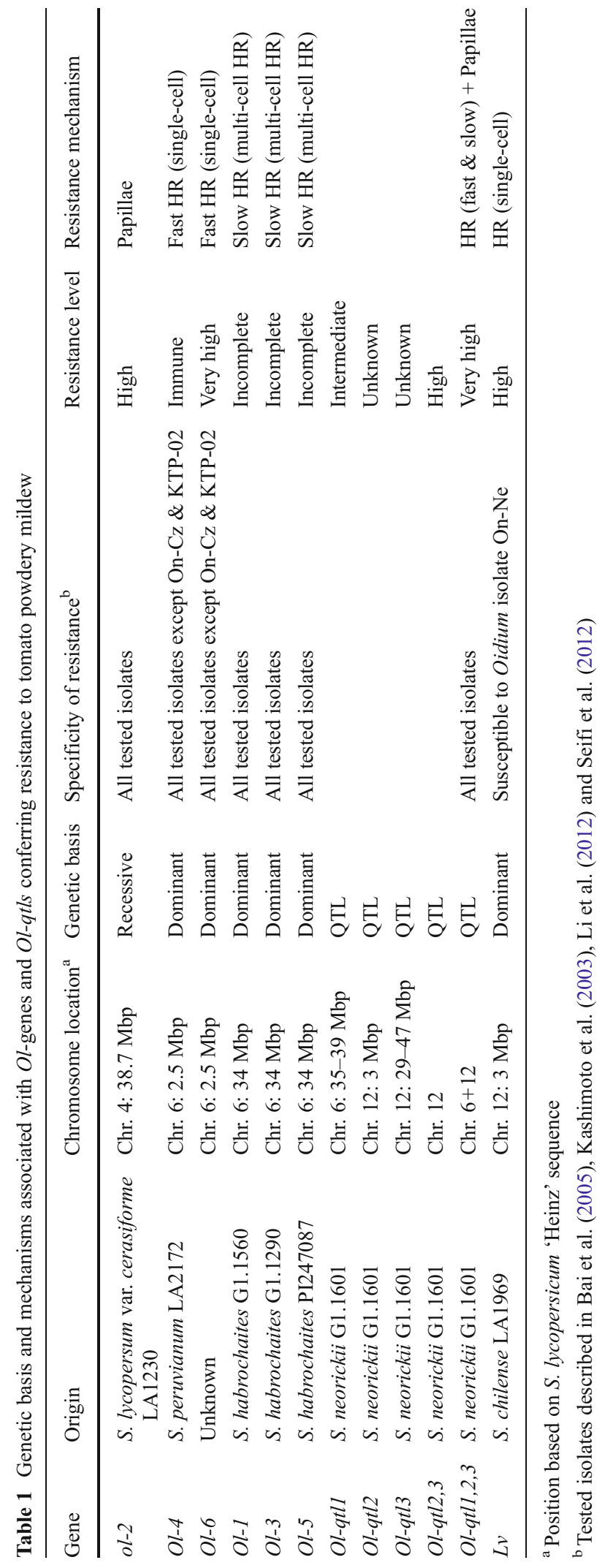




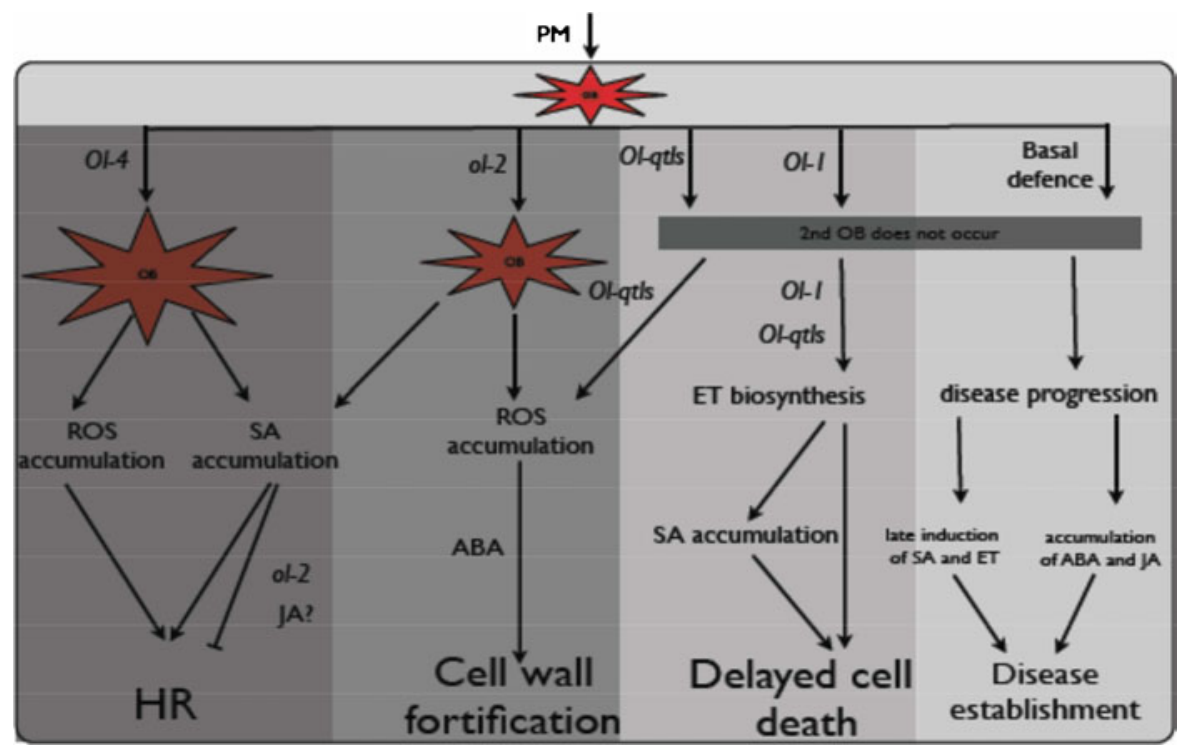

Fig. 4 A proposed model for different tomato responses to PM. Upon infection of a tomato epidermal cell by PM, an oxidative burst (OB) occurs in this cell, regardless of the identity of the cell (resistant or susceptible). In the presence of $\mathrm{Ol}-4$ or $\mathrm{ol}-2$, this initial $\mathrm{OB}$ is exaggerated and results in a second and stronger $\mathrm{OB}$, which accumulates reactive oxygen species (ROS) and triggers SA pathway. The magnitude of this OB exaggerated by $\mathrm{Ol}-4$ is strong enough to promote HR. However, OB exaggerate by $o l-2$ is relatively weaker and also this gene, probably in coordination with JA pathway, has the ability to block the pathways which would result in HR. Instead, ol-2 triggers recruitment of ROS produced upon $\mathrm{OB}$ for reinforcement of the cell wall. This pathway probably requires ABA. The second

cell HR to stop fungal growth after penetration (Hückelhoven et al. 2000).

Though there are differences between barley resistance to $B g h$ and tomato resistance to $O$. neolycopersici, similarities are obviously present $(\mathrm{Li}$ et al. 2007): the recessive mlo-based resistance (mlo-5 and $o l-2)$, fast HR-associated resistance governed by the dominant genes $\mathrm{Ol}-4$ (HR at primary haustorium stage) and $M l g$ (HR at primary appressorium stage), and slow HR-associated resistance by the dominant genes of $\mathrm{Ol}-1$ and Mla12.

In barley, the complex Mla locus (located in a chromosomal interval of $\sim 250 \mathrm{~kb}$ ) contains eight CCNBS-LRR genes (Table 2), of which more than 30 alleles are known to confer race-specific resistance to Bgh (Jørgensen and Wolfe 1994; Wei et al. 2002; Seeholzer et al. 2010). Similarly, the Ol-1, Ol-3 and Ol-5 genes are clustered in a short chromosomal region (Bai et al. 2005). The resistance conferred by Mla genes
OB probably does not occur in the presence of Ol-qtls, Ol-1 and MM (basal defence). Instead, Ol-qtls and Ol-1 lead to DCD by triggering ET accumulation, probably by triggering SA pathway or in collaboration with this pathway. Ol-qtls also triggers callose deposition in an ABA-dependent manner. In the absence of these $\mathrm{Ol}$ resistance genes, i.e., in the basal defence of Moneymaker, neither strong early induction in SA pathway and ROS accumulation, nor late induction of ET pathway occurs, resulting in the establishment of PM. In this picture the intensity of the grey colour represents the level of resistance, which is the highest in the presence of $\mathrm{Ol}-4$ and gradually decreases to basal resistance (Adapted from Seifi 2011)

(i.e., Mla6 and Mla12) is SA independent (Hückelhoven et al. 1999). The Ol-1 gene most probably does not encode an NBS-LRR protein (Seifi 2011), while the $\mathrm{Ol}-4$ and $\mathrm{Ol}-6$ are shown to be homologues of the $\mathrm{Mi}$ 1 gene, thus encoding a CC-NBS-LRR protein (Seifi et al. 2011). The resistance conferred by $\mathrm{Ol}-4 / \mathrm{Ol}-6$ is race-specific and likely SA-dependent.

The Mlo gene encodes a $65 \mathrm{KDa}$ membrane protein with seven transmembrane domains. Loss of function of this gene results in a broad-spectrum resistance to barley powdery mildew (Tables 1 and 2) (Büschges et al. 1997). In tomato the ol-2 gene is a loss-of-function allele of the tomato Mlo ortholog (SlMlo1) (Bai et al. 2008).

Comparison of PM resistance in tomato and Arabidopsis

In Arabidopsis thaliana, four powdery mildew species are known to establish compatible interactions 


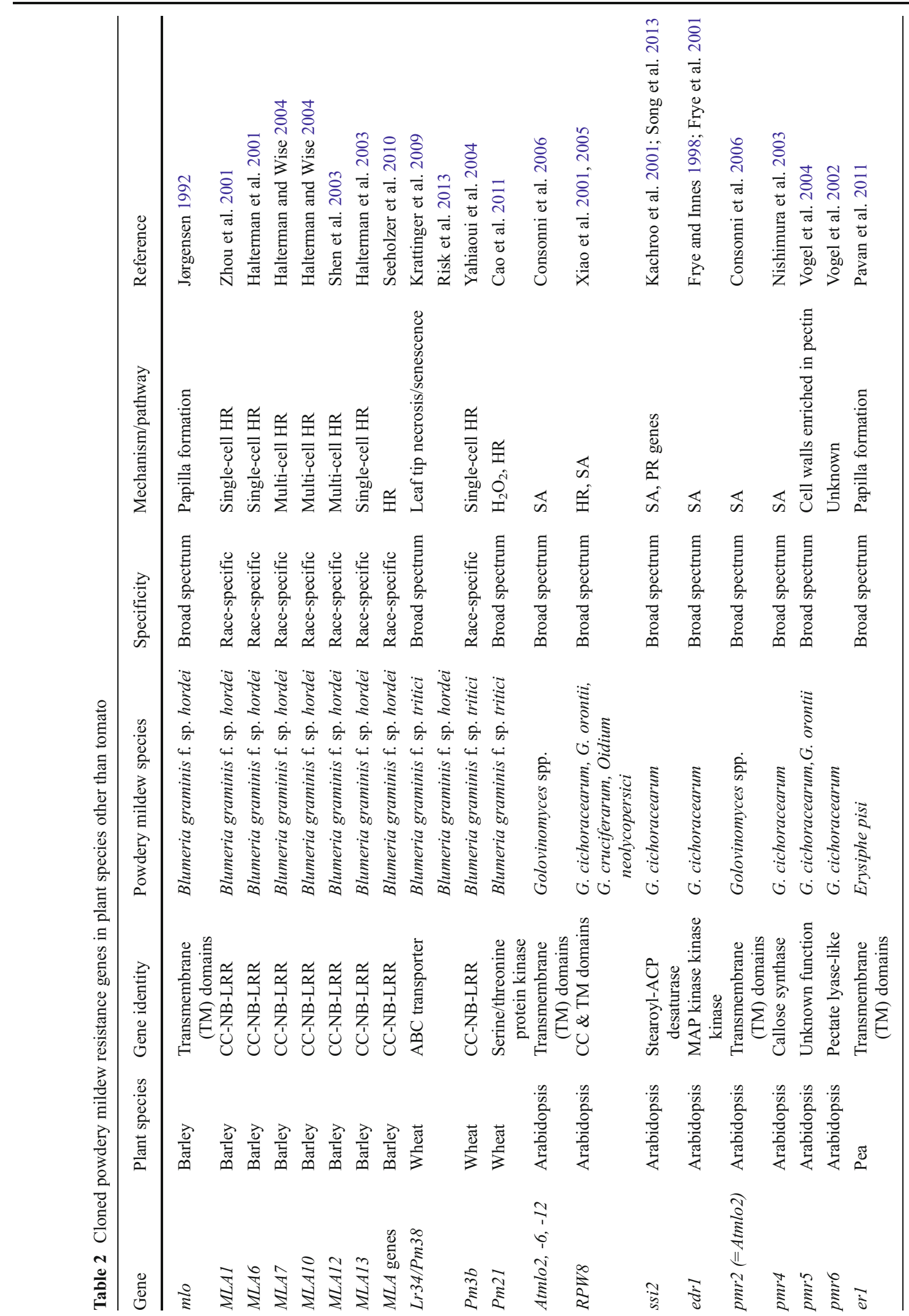


including Golovinomyces spp. and $O$. neolycopersici (Xiao et al. 2001). Known sources of resistance in Arabidopsis comprise natural resistance conferred by alleles of the $R P W 8$ locus and mutation-induced resistance. The $R P W 8$ locus comprises two dominantly inherited $R$-genes, $R P W 8.1$ and $R P W 8.2$, which control resistance to a broad range of PM species (Xiao et al. 2001). RPW8 proteins contain a predicted coiled-coil (CC) and a transmembrane (TM) domain, structurally different from other $\mathrm{R}$ proteins identified to date (Table 2). Though RPW8-mediated resistance was previously reported to be effective against $O$. neolycopersici in the Ms-0 accession, heterologous expression of $R P W 8$ genes in tomato and Arabidopsis failed to confer enhanced resistance to $O$. neolycopersici (Xiao et al. 2001). The RPW8-mediated resistance present in several other Arabidopsis accessions seems to be non-functional against $O$. neolycopersici. Instead, at least two other major loci in the accession Bay-0 appear to mediate such a resistance (Göllner et al. 2008), demonstrating that genetic factors in Arabidopsis for resistance to $O$. neolycopersici are different from those to Golovinomyces spp. Very likely, O. neolycopersici delivers effector(s) that is/are different from the ones delivered by Golovinomyces spp. and is/are able to evade $R P W 8$-mediated recognition. This is supported by the fact that no RPW8 homologues have been identified in cultivated tomato and some wild species (Personal communication, Dr. S. Xiao, Institute of Bioscience and Biotechnology Research, The University of Maryland, USA).

The induced resistance via loss-of-function mutations is represented by powdery mildew resistant (pmr) mutants (pmrl to pmr6) (Vogel and Somerville 2000; Vogel et al. 2002, 2004). Four Pmr genes have been cloned and they are involved in different cellular activities (Table 2). The pmr 2 turned out to be an mlomutant (Atmlo2); Pmr4 encodes a callose synthase, Pmr 5 belongs to a large family of plant-specific genes with unknown function and Pmr6 encodes a putative pectate lyase. In Arabidopsis, unequal genetic redundancy between three phylogenetically closely related Mlo orthologs (AtMlo2, AtMlo6 and AtMlo12) is observed. Absence of AtMlo2 confers partial PM resistance, which is enhanced in Atmlo2 Atmlo6 or Atmlo2 Atmlo12 double mutants. Full resistance requires loss of function of all three co-orthologs; i.e., an Atmlo2 Atmlo6 Atmlo12 triple mutant is completely resistant (Consonni et al. 2006). The Atmlo2-conferred resistance to Golovinomyces spp. is largely independent of the SA signalling pathway (Consonni et al. 2006). However, we found that Atmlo2 resistance to $O$. neolycopersici is broken by the impairment of SA signalling in Atmlo2/eds5, Atmlo2/npr1, Atmlo2/pad4 and Atmlo2/sid2 double mutants and in the Atmlo2/NahG line, resulting in extremely susceptible phenotypes (Zheng 2012). The early senescence phenotype of Atmlo2 mutants is suppressed by the impairment of SA signalling (Consonni et al. 2006; Yoshimoto et al. 2009). Together, these findings indicate that AtMlo2 might also function as a negative regulator of the SA pathway and that SA up-regulation might be an important feature of Atmlo2 resistance to O. neolycopersici.

Cloned genes for resistance to PMs in other plant species

We tried to summarize all the cloned genes for PM resistance in different plant species, including the ones discussed above (Table 2). In wheat there are 59 resistance genes mapped in 43 different loci, conferring resistance to PM caused by $B$. graminis $\mathrm{f}$. sp. tritici (He et al. 2009). Up to now, three of these genes, Pm3b, Pm21 and Lr34/Pm38, have been cloned. $P m 3 b$, which confers race-specific resistance, encodes a CC-NBS-LRR protein (Yahiaoui et al. 2004). Lr34/Pm 38 encodes an ABC transporter and confers race-non-specific resistance (Krattinger et al. 2009). Pm21 encodes a serine/threonine protein kinase, which is present in membrane, cytosol and nucleus of epidermal cells. Pm21 confers durable and broad-spectrum resistance, which is associated with HR (Cao et al. 2011).

\section{Pathogenomics: powdery mildew effectors}

From the genome sequences of three PM species, $B g h$, G. orontii, and E. pisi, it is revealed that PMs have a large, expanded genome up to four times larger than other Ascomycete species (Spanu et al. 2010). Strikingly, the number of protein-coding genes is lower than that in filamentous fungi, but a large portion of the genome consists of transposable elements (TEs); for instance $67 \%$ of the genome in B. graminis (Spanu et al. 2010). It is proposed that the low number of 
protein-coding genes in the genomes of biotrophic fungi explains their obligate nature, and massive proliferation of TEs might be a mechanism to increase genetic variation (Spanu 2012).

Till now, only two PM effectors, namely Avra10 and Avrk1, have been cloned. These genes were isolated by map-based cloning from $B g h$, and their products are recognized by barley R proteins MLA10 and MLK1, respectively (Ridout et al. 2006). With the available PM genomes, plenty of genes encoding for putative effectors, i.e., genes encoding for proteins that have a secretion signal and have no match in organisms outside the PMs, have been identified. Following this algorithm, 248 candidate secreted effector protein (CSEP) were found, most of them highly expressed in haustoria (Spanu 2012). Later by searching for homologues of these CSEPs in the Bgh genome, the number of effector candidates increased to 491 (Pedersen et al. 2012).

Interestingly, these CSEP-encoding genes are highly conserved between different isolates of $B g h$ (Hacquard et al. 2013) but not among other sequenced PMs (Spanu 2012). For instance, only 16 out of 491 CSEPs form B. graminis are conserved in G. orontii and E. pisi (Pedersen et al. 2012). The lack of conservation in putative effector genes in different PMs suggests that evolution of effectors is highly dependent on species-specific adaptation. Since the CSEPS varied among different PMs, the genome information of the three aforementioned PMs is not very useful to fish out putative effectors in other PMs like $O$. neolycopersici, based on homology.

The CSEPs of $B g h$ are not or are barely expressed in germinating spores, but successive waves of massive expression of these genes was detected during and after penetration to barley epidermis (Hacquard, et al. 2013). In incompatible interactions (e.g., presence of Mlal gene) the CSEPS expression decreases following a transcriptional reprogramming in barley epidermal cells and at the onset of cell death in those cells, suggesting a defence mechanism by which host suppresses production or secretion of pathogen's effectors (Hacquard, et al. 2013). Functional analyses of 50 of these CSEPS showed that silencing of eight of them, which are similar to glucosyltransferases, metalloproteases, and microbial secreted ribonucleases, inside the pathogen compromised disease development (Pliego et al. 2013). The ribonuclease-like effectors probably interfere with programed cell death in the host cells and, therefore, help establishment of pathogenicity (Pliego et al. 2013). In another study, it was shown that one of the CSEPs (CSEP0055) interacts with apoplastic pathogenesis-related proteins of barley, including PR17, and thereby suppresses the host defence (Zhang et al. 2012).

With the available PM genomes, the RNAseq approach is very appealing to identify effectors in PM's transcriptome. For example, mRNA extracted from the fugal haustoria of $G$. orontii was sequenced (Weßling et al. 2012). In this study, authors identified 70 CSEPs of which 19 are among the top 50 expressed secreted proteins during the interaction with Arabidopsis (Weßling et al. 2012). We have taken a similar approach to analyse haustorial transcriptome of $O$. neolycopersici with the aim to identify putative effectors of this pathogen.

\section{A retrospect of Zig-Zag model based on plant-PM interactions}

The Zig-Zag model is proposed based on biotrophic interactions (Jones and Dangl 2006), hence mechanisms of plant interactions with PMs should fit well in this model. Here we discuss different forms of plant resistances to PMs in the frame of the Zig-Zag model. The aim is to summarize and organize all the mechanisms of resistance to PMs, and also to validate this model to explain plant-PM interactions.

\section{ETI: race-specific resistance mediated by $R$-genes}

Breeding for resistance has been focused on introducing $R$-genes that encode proteins, which recognize specific pathogen effector proteins leading to ETI (host resistance). This type of host resistance is frequently broken as new pathogen races constantly appear, which forms a bottleneck for durable resistance breeding. The resistance mediated by genes like $\mathrm{Ol}-4$, Ol-6, Pm3b, Mla1 and Mla10 fits well with the criteria of ETI, since these genes encode NBS-LRR proteins, confer race-specific resistance, and induce $\mathrm{HR}$ response. For few of this type of genes, the interacting pathogen effector is also identified and further verifies that these genes perceive a pathogen's effector and trigger ETI. For example barley MLA10 recognizes $\mathrm{AVR}_{\mathrm{A} 10}$ effector from $\mathrm{Bgh}$ (Ridout et al. 2006). 
PTI: race-non-specific resistance conferred by PAMP-receptors

Among the genes that have been discussed above, some do not encode NBS-LRR proteins and confer race nonspecific resistance. For example, $P m 21$ induces strong HR to prevent formation of primary haustoria, encodes a serine/threonine kinase protein and confers a broadspectrum resistance. Although genes like Pto, FLS2, Xa21, PBS1, Rpg5, and Yr36 that confer resistance to different pathogens in different plants, also encode proteins with a serine/threonine kinase domain, however, the homology between these genes and Pm21 is lower that $40 \%$ (Cao et al. 2011). Similarly, the $\mathrm{Ol}-1$ gene and Ol-qtls confer race non-specific resistance by mediating slow HR. We have fine-mapped $\mathrm{Ol}-1$ locus to an $85 \mathrm{~Kb}$ interval, in which there is no NBS-LRR gene, and the annotation of the candidate genes ( 9 genes) suggests that they are involved in metabolic pathways, and not in known defence responses (Seifi 2011). Our preliminary data showed that the Ol-qtl2 does not belong to NBS$L R R$ gene family either (unpublished data). PTI is defined by a set of PAMP-receptors that recognize PAMPs, leading to activation of a range of basal defence mechanisms contributing to resistance with a broad spectrum. At this stage, we cannot rule out the possibility that any of these genes encode for a PAMP-receptor, but the predictions of intracellular localization of the proteins encoded by these genes, and lack of similarity of them with known PAMP receptors, suggests a very low probability for this scenario.

Besides the Pm21 gene, the Lr34/Pm38 gene conferring partial resistance to leaf rust, stripe rust and stem rust, also confers resistance to PM in wheat (Spielmeyer et al. 2008). This gene encodes an ATPbinding cassette (ABC)-transporter, located in the plasma membrane (Krattinger et al. 2009). Biochemical and cytological studies showed that Lr34-mediated resistance is not based on ROS accumulation, callose deposition and HR induction (Rubiales and Niks 1995; Risk et al. 2012). The molecular mechanism of Lr34-mediated resistance is not well understood, but there is evidence suggesting that it is similar to the mechanism induced in response to abiotic stresses and possibly is related to metabolic pathways (Hulbert et al. 2007; Bolton et al. 2008). Interestingly, ectopic expression of Lr34 in barley resulted in resistance against barley leaf rust and barley PM, implying that the substrate and mechanisms of LR34 transporter are conserved between barley and wheat, and thus, promises the possibility of using this valuable gene in cereal breeding for durable resistance (Risk et al. 2013).

The Zig-Zag model formulates the process of arms races between the host and the pathogen and provides a simple and useful model for pathogen-host coevolution studies. However, it is an oversimplification of reality on the post-perception pathways leading to immunity responses. Firstly, this model is based on a clear distinction between PAMPs and effectors in pathogens, and their distinct receptors in the host cells. Recent studies revealed that this distinction is not easy to make in most cases (Thomma et al. 2011). For example, bacterial flagellin and lipopolysaccharide (LPS) are considered as PAMPs, however modifications in these molecules influence bacterial virulence, too (Taguchi et al. 2006, 2010; Naito et al. 2008; Newman et al. 2007), and thus they resemble bacterial effectors. On the other hand, it is not always true that effectors are perceived by $\mathrm{R}$ proteins; there is evidence of perception of apoplastic effectors by PAMP-receptors (de Jonge et al. 2010; Win et al. 2012). In addition, as the above mentioned non- $R$ genes Pm21 and Lr34 encode neither $\mathrm{R}$ proteins nor PAMP-receptors, can we call this kind of resistance PTI? Secondly, the Zig-Zag model boils down the complex innate immune system into two forms of responses, PTI and ETI, merely based on the type of the pathogen receptors, assuming that the post-perception processes are similar in PTI and ETI and only their magnitude is different (Jones and Dangl 2006; Tsuda and Katagiri 2010). Recently, this difference in the magnitude of induction of downstream pathways between ETI and PTI has been questioned. Based on evidence from different pathosystems it seems that a more realistic view is that depending on specific interactions and even environmental conditions, both ETI and PTI could trigger strong or weak responses (Thomma et al. 2011). Last but not least, Lebeda et al. (2013) demonstrated that the non-host resistance to PMs is also associated with HR, a hallmark of resistance conferred by $R$-genes. Therefore, a clear distinction between PTI and ETI is difficult to claim (Thomma et al. 2011).

Nonhost-like resistance conferred by editing plant $S$-genes

Based on the Zig-Zag model, pathogens have to suppress PTI in order to overcome non-host resistance, 
for which pathogen effectors and their host targets play a central role. The absence of certain host-factors (also known as effector targets) encoded by plant susceptibility genes (S-genes) (Eckardt 2002) enable plants to escape the defence suppression and thus to maintain their non-host status (Fig. 5, middle panel). One example is the Xa13 gene encoding a host factor targeted by the TAL effector of Xanthomonas oryzae pv oryzae. Natural mutant xal3 alleles results in resistance to bacteria strains that use the PthXo1 effector (Yuan et al. 2009).

Though there is no evidence showing that the MLO protein is targeted by PM effectors, the Mlo gene is one of the well-characterized $S$-gene examples, which negatively regulates the two Pen genes involving in pathways for nonhost resistance to PMs. In barley, Arabidopsis, tomato, pepper, and pea, loss-offunction mutations in Mlo result in efficient preinvasion resistance to adapted PMs, and orthologs of this gene have been found in the genome of wheat, rice, maize, and grapevine (reviewed by Zheng 2012).

In addition to the mlo and pmr mutants, a considerable number of $S$-genes have been identified in Arabidopsis (reviewed by Pavan et al. 2010); e.g., downy mildew resistance (dmrl to 6) mutants (Van Damme et al. 2005). Based on studies on effectortriggerred susceptibility and by looking from a different point of view into host and non-host resistance (Fig. 5), we proposed in 2010 a novel breeding strategy: disabling plant $S$-genes to achieve non-host-like resistance (Pavan et al. 2010). We are currently verifying whether silencing tomato orthologs of these Arabidopsis $S$-genes leads to resistance to $O$. neolycopersici. Our results till now showed that (1)
Arabidopsis $d m r l$ and pmr4 mutants are resistant to $O$. neolycopersici and, (2) silencing SlDmrl and SlPmr4 in tomato results also in resistance to $O$. neolycopersici (Huibers et al. 2013). Together with the tomato ol-2 mutant (Slmlo1), our results demonstrate that orthologs of Arabidopsis $S$-genes are present in crops and disruption in their $S$-gene function leads to resistance to different pathogens.

\section{Outlook on breeding perspectives}

Non-host resistance is defined as a resistance in all genotypes of a plant species to all genotypes of a pathogen species. Thus, non-host resistance is a durable and a common type of plant resistance to potential pathogens and therefore a valuable trait that can be potentially exploited to control adapted pathogens. However, little is known about the genetic factors and molecular mechanisms associated with non-host resistance. The use of mutants in Arabidopsis has advanced our understanding on mechanisms of non-host resistance to PMs. Three genes known as Pen1, Pen 2, Pen 3 genes, encoding a syntaxin protein, a glycosyl hydrolase, and an ABC-transporter, respectively (Collins et al. 2003; Consonni et al. 2006) have been found to be associated with non-host resistance to PMs (Lipka et al. 2005, 2010). In the review paper by Niks and Marcel (2009), it is suggested that the molecular basis of non-host resistance is very similar to that in basal defence.

Two models of non-host resistance are adapted to the above described Zig-Zag concept (Schweizer 2007). According to the first postulation non-host

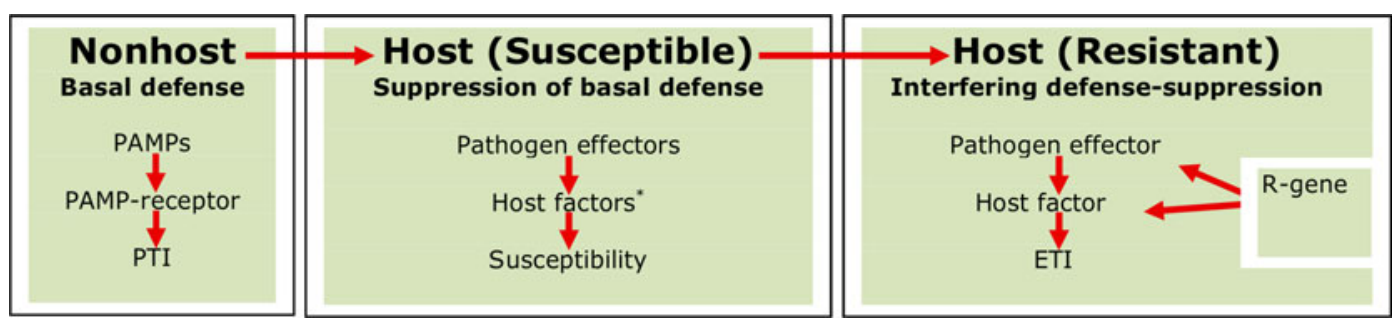

Fig. 5 Plant innate immunity: the Zig-Zag model from a breeding point of view. Left panel perception of PAMPs (pathogen-associated molecular patterns) by PAMP-receptors leads to PAMP-triggered immunity (PTI), which contributes to nonhost (basal) resistance. Middle panel plant host factors targeted by pathogen effector resulting in effector-triggered susceptibility (ETS). * When this host factor (effector target) cannot be exploited by pathogen effectors, plants will maintain their nonhost status. Right panel perception of pathogen effectors by plant resistance $(\mathrm{R})$ proteins (directly or indirectly) leading to effector-triggered immunity (ETI). When multiple R-genes are present in a plant for the same pathogen species, the combined ETI will lead theoretically to nonhost resistance 
resistance is simply because of inadaptability of a certain pathogen to a certain plant species. In other words, the pathogen has not evolved enough to have effectors to suppress PTI (Fig. 5, left panel). The second model anticipates the presence of stacks of multiple $R$-genes that leads to durable resistance by functional redundancy in simultaneously recognizing a number of pathogen effectors (multiple ETI, Fig. 5, right panel). In the future, the identified components for PTI (PAMPs and their receptors) and ETI ( $R$-genes, effectors and their host targets) will be interconnected to unravel the genetics and molecular mechanisms behind disease resistance/susceptibility in order to understand how a plant can or cannot be exploited by a pathogen as a host (Fig. 5). For example, what are the features of effector targets, which can be exploited by adapted pathogens to turn a plant species from a nonhost into a host? In other words, which effectors are used by pathogens to make a "jump" from one host to another? The study of plant $S$-genes and pathogen 'effectoromics' will give fundamental new insights in how pathogens act to suppress plant immunity to promote diseases. As demonstrated above, the knowledge obtained is essential and crucial to open up ways for novel breeding strategies that lead to durable resistance to combat present and future diseases.

From a breeding point of view, non-host resistance is ideal but difficult to achieve. Since current data suggest that molecular basis of nonhost resistance is very similar to those in PTI (Niks and Marcel 2009), the identification of genes contributing to PTI would contribute to resistance with the feature for non-host resistance. In practical programs of resistance breeding, introgression of individual dominant $R$-genes from wild species to cultivated crops still plays a major role. In tomato, the resistance gene $\mathrm{Ol}-4$ can be a perfect candidate for complete resistance to $O$. neolycopersici, nematodes and aphids (Seifi et al. 2011, 2012), being aware that this resistance is race-specific. Dominant resistance is highly effective; however, its race-specific nature makes it vulnerable by the diversity in the genetic pool of the pathogen. In most cases, resistance conferred by $R$-genes can be overcome by pathogens resulting in outbreaks of large epidemics, which 'burst' the once 'booming' cultivars. Repeated boom-and-bust cycles in agriculture continuously force breeders to introduce cultivars with new resistance genes.

Theoretically, pyramiding genes with different specificities and mechanisms can lead to broad- spectrum and durable resistance. For example, the $\mathrm{Ol}$ 1/Ol-3/Ol-5 gene confers incomplete broad-spectrum resistance, thus the combination of these individual genes with $\mathrm{Ol}-4$ will theoretically result in a complete broad-spectrum resistance. For a successful resistance genes pyramiding, several aspects need to be considered including chromosomal location of resistance genes, their specificity, and their resistance pathways.

The chromosomal location of the resistance genes to be pyramided is an important factor. The racespecificities are often conferred by alleles of the same locus (genes located in the same chromosomal position). For example, the Mla locus in barley represents a very "creative" locus that encodes more than 30 different resistance specificities (Mla-1 to Mla32) against barley PM; therefore, accumulation of these Mla alleles in one genotype is impossible by classical breeding. The allelic variants can only be combined in one F1 hybrid in heterozygous status via crossing parental lines with each homozygous for one of these alleles; similar to what is suggested for $T y-1$ and $T y-3$ resistance genes in tomato (Verlaan et al. 2011). In many cases, $R$-genes tend to be clustered. An example is the $\mathrm{Mi}-\mathrm{l}$ gene cluster on tomato chromosome 6, which contains two $\mathrm{Cf}$ genes (Cf-2 and Cf-5) conferring resistance to Cladosporium fulvum, the $\mathrm{Mi}-1$ gene, as well as $\mathrm{Ol}-4$ and $\mathrm{Ol}-6$ (Seifi et al. 2011). The clustering of these resistance genes renders considerable challenges to plant breeders to introgress and pyramid these genes in one breeding line, especially when suppression of recombination is present in such a cluster (Verlaan et al. 2011). Luckily, some $R$-gene clusters are actually natural pyramids of resistance genes to different pathogens; for instance we have shown that the closely linked or the same $M i-1$ homologues in NIL-Ol-4 confer resistance to PM, nematodes and aphids (Seifi et al. 2011).

To achieve durable resistance, the combined genes should have complimentary race-specificities. Also, the downstream pathways involved in the resistance of the pyramided genes need to be in parallel and not antagonistic. Otherwise, the cross-talk and interaction of defence pathways may result in negative interaction between resistances conferred by the combined resistance genes. For instance, resistance mediated by $\mathrm{Ol}-1$ and $\mathrm{Ol}-4$ comes from induction of two different forms of PCD with different hormonal pathways involved. There is a risk that in plants containing both $\mathrm{Ol}-1$ and $\mathrm{Ol}-4$ genes, the PCDtriggering pathways antagonize each other. 
In addition to introgressing resistance genes from wild species, we demonstrated that silencing $S$-genes leads to non-host-like resistance. Since $S$-genes encode proteins that are manipulated by the pathogens, and most probably this manipulation is through effectors, an alternative approach to accelerate discovery of $S$ genes is to look for effector's targets (Gawehns et al. 2013). The main problem associated with the $S$-gene breeding strategy is to find $S$-genes for which loss-of function has no pleiotropic effect on plant growth and development, while it diminishes their function as the susceptibility factor. There are promising results from targeted engineering of $S$-genes, in order to disturb only the $S$-gene function. One successful example is the mutations induced via TALEN-based disruption in the rice bacterial blight $S$-gene $O s 11 N 3$ that interfere with $S$-gene function but not with the developmental function of $O s 11 N 3$ (Li et al. 2012).

An emerging breeding method for pathogen resistance is based on the importance of plant RNA silencing pathways to silence PM's genes. HIGS phenomenon was first observed in barley- Bgh interaction (Nowara et al. 2010) and now the idea has provided a method to investigate the role of pathogen genes (Pliego et al. 2013). It also suggests a potential approach to engineering plants for resistance to PMs (Nowara et al. 2010).

\section{Conclusion and future challenges}

In this review, we summarized the current understanding of the mechanisms by which plants mount defence against different PMs, and also discussed different breeding approaches that are deduced from these resistance mechanisms. A relatively clear picture of the genetics and molecular basis of plant response to PMs is assembled now, however, many other aspects of that are still blurry and demand future investigations.

The pathogenicity mechanisms adopted by PMs to dampen the plant immune system (or to turn a non-host plant species into a host one) are largely unknown, and only recently have we started to discover PM effectors and their mode of action. Scanning the genome of different PM species has resulted in discovery of relatively a large number of putative PM effectors, and now the challenge is to perform functional analysis on these putative effectors in order to get a better understanding of pathogenicity process of PMs. This will also pave the way to further research on the identification of plant factors (especially the ones coded by plant $S$-genes) targeted by PM effectors. Plant $S$-genes, as anticipated in the previous paragraph, could be conveniently manipulated in breeding in order to introduce broad-spectrum and durable forms of resistance.

Crop production is affected by both biotic and abiotic stress factors, thus the best-selling cultivars are those with stable high quality and high yield even under a combination of environmental stresses. In this review, we have focused on PM resistance without taking into account the influence of abiotic stresses. However, it has been demonstrated that environmental conditions influence the outcome of plant-PM interactions (reviewed by Lebeda et al. 2013). Using our NILs, we are currently investigating to what extent pathways for resistance to PM and tolerance to abiotic stresses are shared, and how abiotic stresses might modify resistance responses mediated by different $\mathrm{Ol}$ genes and QTLs. Understanding these responses will enable fine-tuning of breeding efforts towards breeding plants with enhanced PM resistance that can exhibit high level of resistance and maintain their performance under conditions of combined stress.

Open Access This article is distributed under the terms of the Creative Commons Attribution License which permits any use, distribution, and reproduction in any medium, provided the original author(s) and the source are credited.

\section{References}

Achuo, E., Audenaert, K., Meziane, H., \& Höfte, M. (2004). The salicylic acid-dependent defence pathway is effective against different pathogens in tomato and tobacco. Plant Pathology, 53(1), 65-72.

Achuo, E., Prinsen, E., \& Höfte, M. (2006). Influence of drought, salt stress and abscisic acid on the resistance of tomato to Botrytis cinerea and Oidium neolycopersici. Plant pathology, 55(2), 178-186.

Anandalakshmi, R., Marathe, R., Ge, X., Herr, J., Mau, C., Mallory, A., et al. (2000). A calmodulin-related protein that suppresses posttranscriptional gene silencing in plants. Science, 290(5489), 142-144.

Anderson, J. P., Badruzsaufari, E., Schenk, P. M., Manners, J. M., Desmond, O. J., Ehlert, C., et al. (2004). Antagonistic interaction between abscisic acid and jasmonate-ethylene signaling pathways modulates defense gene expression and disease resistance in Arabidopsis. The Plant Cell, 16(12), 3460-3479.

Ausubel, F. M. (2005). Are innate immune signaling pathways in plants and animals conserved? Nature Immunology, 6(10), 973-979. 
Bai, Y., \& Lindhout, P. (2007). Domestication and breeding of tomatoes: what have we gained and what can we gain in the future? Annals of Botany, 100(5), 1085-1094.

Bai, Y., Huang, C.-C., van der Hulst, R., Meijer-Dekens, F., Bonnema, G., \& Lindhout, P. (2003). QTLs for tomato powdery mildew resistance (Oidium lycopersici) in Lycopersicon parviflorum G1. 1601 co-localize with two qualitative powdery mildew resistance genes. Molecular Plant-Microbe Interactions, 16(2), 169-176.

Bai, Y., Van der Hulst, R., Huang, C., Wei, L., Stam, P., \& Lindhout, P. (2004). Mapping Ol-4, a gene conferring resistance to Oidium neolycopersici and originating from Lycopersicon peruvianum LA2172, requires multi-allelic, single-locus markers. Theoretical and Applied Genetics, 109(6), 1215-1223.

Bai, Y., van der Hulst, R., Bonnema, G., Marcel, T. C., MeijerDekens, F., Niks, R. E., et al. (2005). Tomato defense to Oldium neolycopersici: Dominant $\mathrm{Ol}$ genes confer isolatedependent resistance via a different mechanism than recessive ol-2. Molecular Plant-Microbe Interactions, 18(4), 354-362.

Bai, Y., Pavan, S., Zheng, Z., Zappel, N. F., Reinstädler, A., Lotti, C., et al. (2008). Naturally occurring broad-spectrum powdery mildew resistance in a Central American tomato accession is caused by loss of mlo function. Molecular PlantMicrobe Interactions, 21(1), 30-39.

Bardin, M., Suliman, M. E., Sage-palloix, A. M., Mohamed, Y. F., \& Nicot, P. C. (2007). Inoculum production and longterm conservation methods for cucurbits and tomato powdery mildews. Mycological Research, 111(6), 740-747.

Bari, R., \& Jones, J. D. G. (2009). Role of plant hormones in plant defence responses. Plant Molecular Biology, 69(4), 473-488.

Bhat, R. A., Miklis, M., Schmelzer, E., Schulze-Lefert, P., \& Panstruga, R. (2005). Recruitment and interaction dynamics of plant penetration resistance components in a plasma membrane microdomain. Proceedings of the National Academy of Sciences of the United States of America, 102(8), 3135-3140.

Blancard, D. (2012). Tomato diseases: Identification, biology and control. Manson Publishing.

Bolton, M. D., Kolmer, J. A., Xu, W. W., \& Garvin, D. F. (2008). Lr34-mediated leaf rust resistance in wheat: Transcript profiling reveals a high energetic demand supported by transient recruitment of multiple metabolic pathways. Molecular Plant-Microbe Interactions, 21(12), 1515-1527.

Braun, U., \& Cook, R. T. (2012). Taxonomic manual of the Erysiphales (powdery mildews). Utrecht: CBS-KNAW Fungal Biodiversity Centre. 707 pp.

Büschges, R., Hollricher, K., Panstruga, R., Simons, G., Wolter, M., Frijters, A., et al. (1997). The Barley Mlo Gene: A Novel Control Element of Plant Pathogen Resistance. Cell, 88(5), 695-705.

Cao, A., Xing, L., Wang, X., Yang, X., Wang, W., Sun, Y., et al. (2011). Serine/threonine kinase gene Stpk-V, a key member of powdery mildew resistance gene $P m 21$, confers powdery mildew resistance in wheat. Proceedings of the National Academy of Sciences, 108(19), 7727-7732.

Chandran, D., Inada, N., Hather, G., Kleindt, C. K., \& Wildermuth, M. C. (2010). Laser microdissection of Arabidopsis cells at the powdery mildew infection site reveals site-specific processes and regulators. Proceedings of the National Academy of Sciences of the United States of America, 107(1), 460-465.

Chungwongse, J., Bunn, T. B., Crossman, C., Jiang, J., \& Tanksley, S. D. (1994). Chromosomal localization and molecular marker tagging of the powdery mildew resistance gene $(L v)$ in tomato. Theoretical and Applied Genetics, 89(1), 76-79.

Chunwongse, J., Doganlar, S., Crossman, C., Jiang, J., \& Tanksley, S. D. (1997). High-resolution genetic map of the $L v$ resistance locus in tomato. Theoretical and Applied Genetics, 95(1-2), 220-223.

Ciccarese, F., Amenduni, M., Schiavone, D., \& Cirulli, M. (1998). Occurrence and inheritance of resistance to powdery mildew (Oidium lycopersici) in Lycopersicon species. Plant Pathology, 47(4), 417-419.

Collins, N. C., Thordal-Christensen, H., Lipka, V., Bau, S., Kombrink, E., Qiu, J. L., et al. (2003). SNARE-proteinmediated disease resistance at the plant cell wall. Nature, 425(6961), 973-977.

Consonni, C., Humphry, M. E., Hartmann, H. A., Livaja, M., Durner, J., Westphal, L., et al. (2006). Conserved requirement for a plant host cell protein in powdery mildew pathogenesis. Nature Genetics, 38(6), 716-720.

Cooke, M. C., \& Massee, G. (1888). Austalasian fungi. Grevillea. $16,114$.

Dangl, J. L., \& Jones, J. D. (2001). Plant pathogens and integrated defence responses to infection. Nature, 411(6839), 826-833.

de Jonge, R., Peter van Esse, H., Kombrink, A., Shinya, T., Desaki, Y., Bours, R., et al. (2010). Conserved fungal LysM effector Ecp6 prevents chitin-triggered immunity in plants. Science Signaling, 329(5994), 953.

de Torres-Zabala, M., Truman, W., Bennett, M. H., Lafforgue, G., Mansfield, J. W., Egea, P. R., et al. (2007). Pseudomonas syringae pv. tomato hijacks the Arabidopsis abscisic acid signalling pathway to cause disease. The EMBO Journal, 26(5), 1434-1443.

Eckardt, N. A. (2002). Plant disease susceptibility genes? The Plant Cell, 14(9), 1983-1986.

Faino, L., Azizinia, S., Hassanzadeh, B. H., Verzaux, E., Ercolano, M. R., Visser, R. G., et al. (2012). Fine mapping of two major QTLs conferring resistance to powdery mildew in tomato. Euphytica, 184(2), 223-234.

Fan, J., Hill, L., Crooks, C., Doerner, P., \& Lamb, C. (2009). Abscisic acid has a key role in modulating diverse plantpathogen interactions. Plant Physiology, 150(4), 1750-1761.

Flors, V., Ton, J., Jakab, G., \& Mauch-Mani, B. (2005). Abscisic acid and callose: team players in defence against pathogens? Journal of Phytopathology, 153(7-8), 377-383.

Flors, V., Ton, J., Van Doorn, R., Jakab, G., García-Agustín, P., \& Mauch-Mani, B. (2008). Interplay between JA, SA and ABA signalling during basal and induced resistance against Pseudomonas syringae and Alternaria brassicicola. The Plant Journal, 54(1), 81-92.

Freialdenhoven, A., Scherag, B., Hollricher, K., Collinge, D. B., Thordal-Christensen, H., \& Schulze-Lefert, P. (1994). Nar1 and Nar-2, two loci required for Mla12-specified racespecific resistance to powdery mildew in barley. The Plant Cell, 6(7), 983-994.

Freialdenhoven, A., Peterhänsel, C., Kurth, J., Kreuzaler, F., \& Schulze-Lefert, P. (1996). Identification of genes required for the function of non-race-specific mlo resistance to powdery mildew in barley. The Plant Cell, 8(1), 5-14. 
Frye, C. A., \& Innes, R. W. (1998). An Arabidopsis mutant with enhanced resistance to powdery mildew. The Plant Cell, 10(6), 947-956.

Frye, C. A., Tang, D., \& Innes, R. W. (2001). Negative regulation of defense responses in plants by a conserved MAPKK kinase. Proceedings of the National Academy of Sciences of the United States of America, 98(1), 373-378.

Gawehns, F., Cornelissen, B. J., \& Takken, F. L. (2013). The potential of effector-target genes in breeding for plant innate immunity. Microbial Biotechnology, 6(3), 223-229.

Glazebrook, J. (2005). Contrasting mechanisms of defense against biotrophic and necrotrophic pathogens. Annual Review of Phytopathology, 43, 205-227.

Göllner, K., Schweizer, P., Bai, Y., \& Panstruga, R. (2008). Natural genetic resources of Arabidopsis thaliana reveal a high prevalence and unexpected phenotypic plasticity of RPW8-mediated powdery mildew resistance. New Phytologist, 177(3), 725-742.

Grant, M., \& Jones, J. G. (2009). Hormone (dis) harmony moulds plant health and disease. Science, 324, 750-752.

Hacquard, S., Kracher, B., Maekawa, T., Vernaldi, S., SchulzeLefert, P., \& van Themaat, E. V. L. (2013). Mosaic genome structure of the barley powdery mildew pathogen and conservation of transcriptional programs in divergent hosts. Proceedings of the National Academy of Sciences, 110(24), E2219-E2228.

Halterman, D. A., \& Wise, R. P. (2004). A single-amino acid substitution in the sixth leucine-rich repeat of barley MLA6 and MLA13 alleviates dependence on RAR1 for disease resistance signaling. The Plant Journal, 38(2), 215-226.

Halterman, D., Zhou, F., Wei, F., Wise, R. P., \& Schulze-Lefert, P. (2001). The MLA6 coiled-coil, NBS-LRR protein confers AvrMla6-dependent resistance specificity to Blumeria graminis f. sp. hordei in barley and wheat. The Plant Journal, 25(3), 335-348.

Halterman, D. A., Wei, F., \& Wise, R. P. (2003). Powdery mildew-induced Mla mRNAs are alternatively spliced and contain multiple upstream open reading frames. Plant Physiology, 131(2), 558-567.

He, R., Chang, Z., Yang, Z., Yuan, Z., Zhan, H., Zhang, X., et al. (2009). Inheritance and mapping of powdery mildew resistance gene Pm43 introgressed from Thinopyrum intermedium into wheat. Theoretical and Applied Genetics, 118(6), 1173-1180.

Hernandes, R., \& Stamova, L. (1990). Resistance to Leveillula taurica in tomato lines from Costa Rica. Tomato Genetics Cooperative Report, 40, 15.

Huang, C.-C., Groot, T., Meijer-Dekens, F., Niks, R. E., \& Lindhout, P. (1998). The resistance to powdery mildew (Oidium lycopersicum) in shape Lycopersicon species is mainly associated with hypersensitive response. European Journal of Plant Pathology, 104(4), 399-407.

Huang, C., Cui, Y.-Y., Weng, C., Zabel, P., \& Lindhout, P. (2000a). Development of diagnostic PCR markers closely linked to the tomato powdery mildew resistance gene Ol-1 on chromosome 6 of tomato. Theoretical and Applied Genetics, 101(5-6), 918-924.

Huang, C. C., Meijer-Dekens, F., \& Lindhout, P. (2000b). Characterization and mapping of resistance to Oidium lycopersicum in two Lycopersicon hirsutum accessions: evidence for close linkage of two $\mathrm{Ol}$-genes on chromosome 6 of tomato. Heredity, 85(6), 511-520.
Hückelhoven, R. (2005). Powdery mildew susceptibility and biotrophic infection strategies. FEMS Microbiology Letters, 245(1), 9-17.

Hückelhoven, R. (2007). Cell wall-associated mechanisms of disease resistance and susceptibility. Annual Review in Phytopathology, 45, 101-127.

Hückelhoven, R., Fodor, J., Preis, C., \& Kogel, K.-H. (1999). Hypersensitive cell death and papilla formation in barley attacked by the powdery mildew fungus are associated with hydrogen peroxide but not with salicylic acid accumulation. Plant Physiology, 119(4), 1251-1260.

Hückelhoven, R., Fodor, J., Trujillo, M., \& Kogel, K. H. (2000). Barley Mla and Rar mutants compromised in the hypersensitive cell death response against Blumeria graminis f.sp. hordei are modified in their ability to accumulate reactive oxygen intermediates at sites of fungal invasion. Planta, 212(1), 16-24.

Hückelhoven, R., Dechert, C., Trujillo, M., \& Kogel, K. H. (2001). Differential expression of putative cell death regulator genes in near-isogenic, resistant and susceptible barley lines during interaction with the powdery mildew fungus. Plant Molecular Biology, 47(6), 739-748.

Huibers, R. P., Loonen, A. E. H. M., Gao, D., Van den Ackerveken, G., Visser, R. G. F., \& Bai, Y. (2013). Powdery mildew resistance in tomato by impairment of SIPMR4 and SIDMR1. PLoS ONE, 8(6), e67467. doi:10. 1371/journal.pone.0067467.

Hulbert, S. H., Bai, J., Fellers, J. P., Pacheco, M. G., \& Bowden, R. L. (2007). Gene expression patterns in near isogenic lines for wheat rust resistance gene Lr34/Yrl8. Phytopathology, 97(9), 1083-1093.

Jankovics, T., Bai, Y., Kovács, G. M., Bardin, M., Nicot, P. C., Toyoda, H., Matsuda, et al. (2008). Oidium neolycopersici: Intra-specific variability inferred from AFLP analysis and relationship with closely related powdery mildew fungi infecting various plant species. Phytopathology, 98(5), 529-540.

Jin, H. (2008). Endogenous small RNAs and antibacterial immunity in plants. FEBS Letters, 582(18), 2679-2684.

Jones, J. D., \& Dangl, J. L. (2006). The plant immune system. Nature, 444(7117), 323-329.

Jones, H. E., Whipps, J. M., Thomas, B. J., Carver, T. L., \& Gurr, S. J. (2000). Initial events in the colonisation of tomatoes by Oidium lycopersici, a distinct powdery mildew fungus of Lycopersicon species. Canadian Journal of Botany, 78(10), 1361-1366.

Jones, H., Whipps, J. M., \& Gurr, S. J. (2001). The tomato powdery mildew fungus Oidium neolycopersici. Molecular Plant Pathology, 2(6), 303-309.

Jørgensen, I. H. (1992). Discovery, characterization and exploitation of Mlo powdery mildew resistance in barley. Euphytica, 63(1-2), 141-152.

Jørgensen, J. H., \& Wolfe, M. (1994). Genetics of powdery mildew resistance in barley. Critical Reviews in Plant Sciences, 13(1), 97-119.

Kachroo, P., Shanklin, J., Shah, J., Whittle, E. J., \& Klessig, D. F. (2001). A fatty acid desaturase modulates the activation of defense signaling pathways in plants. Proceedings of the National Academy of Sciences of the United States of America, 98(16), 9448-9453.

Kamoun, S. (2007). Groovy times: filamentous pathogen effectors revealed. Current Opinion in Plant Biology, 10(4), 358-365. 
Kashimoto, K., Sameshima, T., Matsuda, Y., Nonomura, T., Oichi, W., Kakutani, K., et al. (2003). Infectivity of a Japanese isolate of Oidium neolycopersici KTP-01 to a European tomato cultivar resistant to $O$. lycopersici. Journal of General Plant Pathology, 69(6), 406-408.

Katiyar-Agarwal, S., \& Jin, H. (2010). Role of small RNAs in host-microbe interactions. Annual Review of Phytopathology, 48, 225-246.

Khodaparast, S. A., Takamatsu, S., \& Hedjaroude, G. A. (2001). Phylogenetic structure of the genus Leveillula (Erysiphales: Erysiphaceae) inferred from the nucleotide sequences of the rDNA ITS region with special reference to the L. taurica species complex. Mycological Research, 105(8), 909-918.

Khodaparast, S. A., Niinomi, S., \& Takamatsu, S. (2007). Molecular and morphological characterization of Leveillula (Ascomycota: Erysiphales) on monocotyledonous plants. Mycological Research, 111(6), 673-679.

Khodaparast, S. A., Takamatsu, S., Harada, M., Abbasi, M., \& Samadi, S. (2012). Additional rDNA ITS sequences and its phylogenetic consequences for the genus Leveillula with emphasis on conidium morphology. Mycological Progress, 11(3), 741-752.

Kiss, L., Cook, R. T., Saenz, G. S., Cunnington, J. H., Takamatsu, S., Pascoe, I., et al. (2001). Identification of two powdery mildew fungi, Oidium neolycopersici sp. nov. and $O$. lycopersici, infecting tomato in different parts of the world. Mycological Research, 105(6), 684-697.

Kiss, L., Takamatsu, S., \& Cunnington, J. H. (2005). Molecular identification of Oidium neolycopersici as the causal agent of the recent tomato powdery mildew epidemics in North America. Plant Disease, 89(5), 491-496.

Krattinger, S. G., Lagudah, E. S., Spielmeyer, W., Singh, R. P., Huerta-Espino, J., McFadden, H., et al. (2009). A putative $\mathrm{ABC}$ transporter confers durable resistance to multiple fungal pathogens in wheat. Science, 323(5919), 1360-1363.

Lamb, C., \& Dixon, R. A. (1997). The oxidative burst in plant disease resistance. Annual Review of Plant Biology, 48(1), 251-275.

Lebeda, A., Mieslerová, B., Petřivalský, M., Luhová, L., Ŝpundová, M., Sedláŕová, M., et al. (2013). Resistance mechanisms of wild tomato germplasm to infection of Oidium neolycopersici. European Journal of Plant Pathology, this issue.

Li, C., Bai, Y., Jacobsen, E., Visser, R., Lindhout, P., \& Bonnema, G. (2006). Tomato defense to the powdery mildew fungus: differences in expression of genes in susceptible, monogenicand polygenic resistance responses are mainly in timing. Plant Molecular Biology, 62(1-2), 127-140.

Li, C., Bonnema, G., Che, D., Dong, L., Lindhout, P., Visser, R., et al. (2007). Biochemical and molecular mechanisms involved in monogenic resistance responses to tomato powdery mildew. Molecular Plant-Microbe Interactions, 20(9), 1161-1172.

Li, C., Faino, L., Dong, L., Fan, J., Kiss, L., De Giovanni, C., et al. (2012). Characterization of polygenic resistance to powdery mildew in tomato at cytological, biochemical and gene expression level. Molecular Plant Pathology, 13(2), 148-159.

Lindhout, P., Pet, G., \& van der Beek, H. (1994). Screening wild Lycopersicon species for resistance to powdery mildew (Oidium lycoperiscum). Euphytica, 72(1-2), 43-49.

Lipka, V., Dittgen, J., Bednarek, P., Bhat, R., Wiermer, M., Stein, M., et al. (2005). Plant science: Pre- and postinvasion defenses both contribute to nonhost resistance in Arabidopsis. Science, 310(5751), 1180-1183.

Lipka, U., Fuchs, R., Kuhns, C., Petutschnig, E., \& Lipka, V. (2010). Live and let die-Arabidopsis nonhost resistance to powdery mildews. European Journal of Cell Biology, 89(2-3), 194-199.

Love, A. J., Milner, J. J., \& Sadanandom, A. (2008). Timing is everything: regulatory overlap in plant cell death. Trends in Plant Science, 13(11), 589-595.

Lund, S., Stall, R., \& Klee, H. (1998). Ethylene regulates the susceptible response to pathogen infection in tomato. The Plant Cell, 10(3), 371-382.

Mantelin, S., Bhattarai, K. K., Jhaveri, T. Z., \& Kaloshian, I. (2013). Mi-1-mediated resistance to Meloidogyne incognita in tomato may not rely on ethylene but hormone perception through ETR3 participates in limiting nematode infection in a susceptible host. PLoS ONE, 8(5), e63281.

Mauch-Mani, B., \& Mauch, F. (2005). The role of abscisic acid in plant-pathogen interactions. Current Opinion in Plant Biology, 8(4), 409-414.

Milligan, S. B., Bodeau, J., Yaghoobi, J., Kaloshian, I., Zabel, P., \& Williamson, V. M. (1998). The root knot nematode resistance gene $\mathrm{Mi}$ from tomato is a member of the leucine zipper, nucleotide binding, leucine-rich repeat family of plant genes. The Plant Cell, 10(8), 1307-1319.

Mlíčková, K., Luhová, L., Lebeda, A., Mieslerová, B., \& Peč, P. (2004). Reactive oxygen species generation and peroxidase activity during Oidium neolycopersici infection on Lycopersicon species. Plant Physiology and Biochemistry, 42(10), 753-761.

Naito, K., Taguchi, F., Suzuki, T., Inagaki, Y., Toyoda, K., Shiraishi, T., et al. (2008). Amino acid sequence of bacterial microbeassociated molecular pattern flg22 is required for virulence. Molecular Plant-Microbe Interactions, 21(9), 1165-1174.

Nakahara, K. S., Masuta, C., Yamada, S., Shimura, H., Kashihara, Y., Wada, T. S., et al. (2012). Tobacco calmodulin-like protein provides secondary defense by binding to and directing degradation of virus RNA silencing suppressors. Proceedings of the National Academy of Sciences, 109(25), 10113-10118.

Newman, M. A., Dow, M. J., Molinaro, A., \& Parrilli, M. (2007). Priming, induction and modulation of plant defence responses by bacterial lipopolysaccharides. Journal of Endotoxin Research, 13(2), 69-84.

Niks, R. E., \& Marcel, T. C. (2009). Nonhost and basal resistance: how to explain specificity? New Phytologist, 182, 817-828.

Nimchuk, Z., Eulgem, T., Holt Iii, B. F., \& Dangl, J. L. (2003). Recognition and response in the plant immune system. Annual Review of Genetics, 37(1), 579-609.

Nishimura, M. T., Stein, M., Hou, B. H., Vogel, J. P., Edwards, H., \& Somerville, S. C. (2003). Loss of a callose synthase results in salicylic acid-dependent disease resistance. Science, 301(5635), 969-972.

Nombela, G., Williamson, V. M., \& Muñiz, M. (2003). The rootknot nematode resistance gene $M i-1.2$ of tomato is responsible for resistance against the whitefly Bemisia tabaci. Molecular Plant-Microbe Interactions, 16(7), 645-649.

Nowara, D., Gay, A., Lacomme, C., Shaw, J., Ridout, C., Douchkov, D., et al. (2010). HIGS: host-induced gene silencing in the obligate biotrophic fungal pathogen Blumeria graminis. The Plant Cell, 22(9), 3130-3141. 
O’Donnell, P. J., Schmelz, E., Block, A., Miersch, O., Wasternack, C., Jones, J. B., et al. (2003). Multiple hormones act sequentially to mediate a susceptible tomato pathogen defense response. Plant Physiology, 133(3), 1181-1189.

Palti, J. (1988). The Leveillula mildews. The Botanical Review, 54(4), 423-535.

Pavan, S., Jacobsen, E., Visser, R. G., \& Bai, Y. (2010). Loss of susceptibility as a novel breeding strategy for durable and broad-spectrum resistance. Molecular Breeding, 25(1), 1-12.

Pavan, S., Schiavulli, A., Appiano, M., Marcotrigiano, A. R., Cillo, F., Visser, R. G. F., et al. (2011). Pea powdery mildew er1 resistance is associated to loss-of-function mutations at a MLO homologous locus. Theoretical and Applied Genetics, 123(8), 1425-1431.

Pedersen, C., van Themaat, E. V. L., McGuffin, L. J., Abbott, J. C., Burgis, T. A., Barton, G., et al. (2012). Structure and evolution of barley powdery mildew effector candidates. BMC Genomics, 13(1), 694-714.

Pei, D., Ma, H., Zhang, Y., Ma, Y., Wang, W., Geng, H., et al. (2011). Virus-induced gene silencing of a putative glutathione S-transferase gene compromised $\mathrm{Ol}-1$-mediated resistance against powdery mildew in tomato. Plant Molecular Biology Reporter, 29(4), 972-978.

Pieterse, C. M., Leon-Reyes, A., Van der Ent, S., \& Van Wees, S. C. (2009). Networking by small-molecule hormones in plant immunity. Nature Chemical Biology, 5(5), 308-316.

Pliego, C., Nowara, D., Bonciani, G., Gheorghe, D. M., Xu, R., Surana, P., et al. (2013). Host-induced gene silencing in barley powdery mildew reveals a class of ribonucleaselike effectors. Molecular Plant-Microbe Interactions, 26(6), 633-642.

Qiao, Y., Liu, L., Xiong, Q., Flores, C., Wong, J., Shi, J., et al. (2013). Oomycete pathogens encode RNA silencing suppressors. Nature Genetics, 45(3), 330-333.

Reinbothe, C., Springer, A., Samol, I., \& Reinbothe, S. (2009). Plant oxylipins: role of jasmonic acid during programmed cell death, defence and leaf senescence. FEBS Journal, 276(17), 4666-4681.

Ridout, C. J., Skamnioti, P., Porritt, O., Sacristan, S., Jones, J. D., \& Brown, J. K. (2006). Multiple avirulence paralogues in cereal powdery mildew fungi may contribute to parasite fitness and defeat of plant resistance. The Plant Cell, 18(9), 2402-2414.

Risk, J. M., Selter, L. L., Krattinger, S. G., Viccars, L. A., Richardson, T. M., Buesing, G., et al. (2012). Functional variability of the $L r 34$ durable resistance gene in transgenic wheat. Plant Biotechnology Journal, 10(4), 477-487.

Risk, J. M., Selter, L. L., Chauhan, H., Krattinger, S. G., Kumlehn, J., Hensel, G., et al. (2013). The wheat Lr34 gene provides resistance against multiple fungal pathogens in barley. Plant Biotechnology Journal. doi:10.1111/pbi. 12077.

Rossi, M., Goggin, F. L., Milligan, S. B., Kaloshian, I., Ullman, D. E., \& Williamson, V. M. (1998). The nematode resistance gene $\mathrm{Mi}$ of tomato confers resistance against the potato aphid. Proceedings of the National Academy of Sciences of the United States of America, 95(17), 9750-9754.

Rubiales, D., \& Niks, R. E. (1995). Characterization of Lr34, a major gene conferring nonhypersensitive resistance to wheat leaf rust. Plant Disease, 79(12), 1208-1212.
Ruiz-Ferrer, V., \& Voinnet, O. (2009). Roles of plant small RNAs in biotic stress responses. Annual Review of Plant Biology, 60, 485-510.

Schulze-Lefert, P., \& Vogel, J. (2000). Closing the ranks to attack by powdery mildew. Trends in Plant Science, 5(8), 343348.

Schweizer, P. (2007). Nonhost resistance of plants to powdery mildew-new opportunities to unravel the mystery. Physiological and Molecular Plant Pathology, 70(1), 3-7.

Seeholzer, S., Tsuchimatsu, T., Jordan, T., Bieri, S., Pajonk, S., Yang, W., et al. (2010). Diversity at the Mla powdery mildew resistance locus from cultivated barley reveals sites of positive selection. Molecular Plant-Microbe Interactions, 23(4), 497-509.

Seifi, A. (2011). Characterization of tomato genes for resistance to Oidium neolycopersici. Wageningen University, $\mathrm{PhD}$ Thesis.

Seifi, A., Kaloshian, I., Vossen, J., Che, D., Bhattarai, K. K., Fan, J., et al. (2011). Linked, if not the same, Mi-1 homologues confer resistance to tomato powdery mildew and root-knot nematodes. Molecular Plant-Microbe Interactions, 24(4), 441-450.

Seifi, A., Nonomura, T., Matsuda, Y., Toyoda, H., \& Bai, Y. (2012). An avirulent tomato powdery mildew isolate induces localized acquired resistance to a virulent isolate in a spatiotemporal manner. Molecular Plant-Microbe Interactions, 25(3), 372-378.

Seo, J.-K., Wu, J., Lii, Y., Li, Y., \& Jin, H. (2013). Contribution of small RNA pathway components in plant immunity. Molecular Plant-Microbe Interactions, 26(6), 617-625.

Shen, Q. H., Zhou, F., Bieri, S., Haizel, T., Shirasu, K., \& Schulze-Lefert, P. (2003). Recognition specificity and RAR1/SGT1 dependence in barley Mla disease resistance genes to the powdery mildew fungus. The Plant Cell, 15(3), $732-744$.

Shirasu, K., \& Schulze-Lefert, P. (2000). Regulators of cell death in disease resistance. Plant Molecular Biology, 44(3), 371385.

Shivaprasad, P. V., Chen, H.-M., Patel, K., Bond, D. M., Santos, B. A., \& Baulcombe, D. C. (2012). A microRNA superfamily regulates nucleotide binding site-leucine-rich repeats and other mRNAs. The Plant Cell, 24(3), 859-874.

Song, N., Hu, Z., Li, Y., Li, C., Peng, F., Yao, Y., et al. (2013). Overexpression of a wheat stearoyl-ACP desaturase (SACPD) gene TaSSI2 in Arabidopsis ssi2 mutant compromise its resistance to powdery mildew. Gene, 524(2), 220-227.

Spanu, P. D. (2012). The genomics of obligate (and nonobligate) biotrophs. Annual Review of Phytopathology, 50, 91-109.

Spanu, P. D., Abbott, J. C., Amselem, J., Burgis, T. A., Soanes, D. M., Stüber, K., et al. (2010). Genome expansion and gene loss in powdery mildew fungi reveal tradeoffs in extreme parasitism. Science, 330(6010), 1543-1546.

Spielmeyer, W., Singh, R., McFadden, H., Wellings, C., HuertaEspino, J., Kong, X., et al. (2008). Fine scale genetic and physical mapping using interstitial deletion mutants of Lr34/Yr18: a disease resistance locus effective against multiple pathogens in wheat. Theoretical and Applied Genetics, 116(4), 481-490.

Stamova, L., \& Yordanov, M. (1987). Resistance to Leveillula taurica (Lev.) Arn. Tomato Genetics Cooperative Report, $37,73$. 
Stamova, L., \& Yordanov, M. (1990). $L v$-as a symbol of the gene controlling resistance to Leveillula taurica. Tomato Genetics Cooperative Report, 40, 36.

Taguchi, F., Ogawa, Y., Takeuchi, K., Suzuki, T., Toyoda, K., Shiraishi, T., et al. (2006). A homologue of the 3-oxoacyl(acyl carrier protein) synthase III gene located in the glycosylation island of Pseudomonas syringae pv. tabaci regulates virulence factors via $\mathrm{N}$-acyl homoserine lactone and fatty acid synthesis. Journal of Bacteriology, 188(24), 8376-8384.

Taguchi, F., Suzuki, T., Inagaki, Y., Toyoda, K., Shiraishi, T., \& Ichinose, Y. (2010). The siderophore pyoverdine of Pseudomonas syringae pv. tabaci 6605 is an intrinsic virulence factor in host tobacco infection. Journal of Bacteriology, 192(1), 117-126.

Thomma, B. P., Nürnberger, T., \& Joosten, M. H. (2011). Of PAMPs and effectors: the blurred PTI-ETI dichotomy. The Plant Cell, 23(1), 4-15.

Tománková, K., Luhová, L., Petřivalský, M., Peč, P., \& Lebeda, A. (2006). Biochemical aspects of reactive oxygen species formation in the interaction between Lycopersicon spp. and Oidium neolycopersici. Physiological and Molecular Plant Pathology, 68(1), 22-32.

Torres, M. A., Jones, J. D., \& Dangl, J. L. (2006). Reactive oxygen species signaling in response to pathogens. Plant Physiology, 141(2), 373-378.

Tsuda, K., \& Katagiri, F. (2010). Comparing signaling mechanisms engaged in pattern-triggered and effectortriggered immunity. Current Opinion in Plant Biology, 13(4), 459-465.

Van Damme, M., Andel, A., Huibers, R. P., Panstruga, R., Weisbeek, P. J., \& Van Den Ackerveken, G. (2005). Identification of Arabidopsis loci required for susceptibility to the downy mildew pathogen Hyaloperonospora parasitica. Molecular Plant-Microbe Interactions, 18(6), 583-592.

Van der Beek, J., Pet, G., \& Lindhout, P. (1994). Resistance to powdery mildew (Oidium lycopersicum) in Lycopersicon hirsutum is controlled by an incompletely-dominant gene Ol-1 on chromosome 6. Theoretical and Applied Genetics, 89(4), 467-473.

Van Esse, H. P., Fradin, E. F., de Groont, P. J., de Wit, P. J. G., \& Thomma, B. P. H. J. (2009). Tomato Transcriptional Responses to a foliar and a vascular fungal pathogen are distinct. Molecular Plant-Microbe Interactions, 22(3), 245-258.

Verlaan, M. G., Szinay, D., Hutton, S. F., de Jong, H., Kormelink, R., Visser, R. G., et al. (2011). Chromosomal rearrangements between tomato and Solanum chilense hamper mapping and breeding of the TYLCV resistance gene Ty-1. The Plant Journal, 68(6), 1093-1103.

Vlot, A. C., Dempsey, D. M. A., \& Klessig, D. F. (2009). Salicylic acid, a multifaceted hormone to combat disease. Annual Review of Phytopathology, 47, 177-206.

Vogel, J., \& Somerville, S. (2000). Isolation and characterization of powdery mildew-resistant Arabidopsis mutants. Proceedings of the National Academy of Sciences, 97(4), 1897-1902.

Vogel, J. P., Raab, T. K., Schiff, C., \& Somerville, S. C. (2002). $P M R 6$, a pectate lyase-like gene required for powdery mildew susceptibility in Arabidopsis. The Plant Cell, 14(9), 2095-2106.
Vogel, J. P., Raab, T. K., Somerville, C. R., \& Somerville, S. C. (2004). Mutations in PMR5 result in powdery mildew resistance and altered cell wall composition. The Plant Journal, 40(6), 968-978.

Voinnet, O. (2005). Induction and suppression of RNA silencing: Insights from viral infections. Nature Reviews Genetics, 6, 206-220.

Wei, F., Wing, R. A., \& Wise, R. P. (2002). Genome dynamics and evolution of the Mla (powdery mildew) resistance locus in barley. The Plant Cell, 14(8), 1903-1917.

Weßling, R., Schmidt, S. M., Micali, C. O., Knaust, F., Reinhardt, R., Neumann, U., van Themaat, E. V. L., \& Panstruga, R. (2012). Transcriptome analysis of enriched Golovinomyces orontii haustoria by deep 454 pyrosequencing. Fungal Genetics and Biology, 49(6), 470-482.

Whipps, J., Budge, S., \& Fenlon, J. (1998). Characteristics and host range of tomato powdery mildew. Plant Pathology, $47(1), 36-48$.

Win, J., Chaparro-Garcia, A., Belhaj, K., Saunders, D., Yoshida, K., Dong, S., et al. (2012). Effector biology of plantassociated organisms: concepts and perspectives. Cold Spring Harbor Symposia on Quantitative Biology, LXXVII.

Xiao, S., Ellwood, S., Calis, O., Patrick, E., Li, T., Coleman, M., et al. (2001). Broad-spectrum mildew resistance in Arabidopsis thaliana mediated by RPW8. Science, 291(5501), 118-120.

Xiao, S., Calis, O., Patrick, E., Zhang, G., Charoenwattana, P., Muskett, P., et al. (2005). The atypical resistance gene, $R P W 8$, recruits components of basal defence for powdery mildew resistance in Arabidopsis. The Plant Journal, 42(1), 95-110.

Yahiaoui, N., Srichumpa, P., Dudler, R., \& Keller, B. (2004). Genome analysis at different ploidy levels allows cloning of the powdery mildew resistance gene $P m 3 b$ from hexaploid wheat. The Plant Journal, 37(4), 528-538.

Yordanov, M., Stamova, L., \& Stoyanova, Z. (1975). Leveillula taurica resistance in the tomato. Tomato Genetics Cooperative Report, 25, 24.

Yoshimoto, K., Jikumaru, Y., Kamiya, Y., Kusano, M., Consonni, C., Panstruga, R., et al. (2009). Autophagy negatively regulates cell death by controlling NPR1dependent salicylic acid signaling during senescence and the innate immune response in Arabidopsis. The Plant Cell, 21(9), 2914-2927.

Yuan, M., Chu, Z., Li, X., Xu, C., \& Wang, S. (2009). Pathogeninduced expressional loss of function is the key factor in race-specific bacterial resistance conferred by a recessive $\mathrm{R}$ gene xa13 in rice. Plant and Cell Physiology, 50(5), 947955.

Zhang, W. J., Pedersen, C., Kwaaitaal, M., Gregersen, P. L., Mørch, S. M., Hanisch, S., \& Thordal-Christensen, H. (2012). Interaction of barley powdery mildew effector candidate CSEP0055 with the defence protein PR17c. Molecular Plant Pathology, 13(9), 1110-1119.

Zheng, Z. (2012) Exploration of mlo-based resistance in vegetable crops. Wageningen University, $\mathrm{PhD}$ Thesis.

Zheng, Z., Nonomura, T., Bóka, K., Matsuda, Y., Visser, R. G., Toyoda, H., et al. (2013a). Detection and quantification of Leveillula taurica growth in pepper leaves. Phytopathology, 103, 623-632. 
Zheng, Z., Nonomura, T., Appiano, M., Pavan, S., Matsuda, Y., Toyoda, K., et al. (2013b). Loss of function in Mlo orthologs reduces susceptibility of pepper and tomato to powdery mildew disease caused by Leveillula taurica. PLOS ONE, 8(7), e70723. doi:10.1371/journal.pone.0070723.
Zhou, F., Kurth, J., Wei, F., Elliott, C., Valè, G., Yahiaoui, N., et al. (2001). Cell-autonomous expression of barley Mlal confers race-specific resistance to the powdery mildew fungus via a Rarl-independent signaling pathway. The Plant Cell, 13(2), 337-350. 